\title{
Desmids (Desmidiaceae, Zygnematophyceae) with cylindrical morphologies in the coastal plains of northern Bahia, Brazil
}

\author{
Ivania Batista de Oliveira ${ }^{1,3}$, Carlos Eduardo de Mattos Bicudo ${ }^{2}$ and Carlos Wallace do Nascimento Moura ${ }^{1}$
}

Received: 21 November, 2012. Accepted: 5 September, 2013

\begin{abstract}
Our knowledge of desmids with cylindrical morphologies in the state of Bahia, Brazil, is quite limited, only 13 such taxa having been described to date. The present study reports the results of a taxonomic inventory of desmids (Desmidiaceae) with cylindrical morphologies from the coastal plains of northern Bahia. During the summer months (January-March) and winter months (June-August) of two separate years (2007 and 2009), we collected a total of 90 samples of planktonic and periphytic material from lotic and lentic environments within three environmentally protected areas within the state (Rio Capivara, Lagoas de Guarajuba, and Litoral Norte). We identified 32 taxa, distributed among six genera (Docidium, Haplotaenium, Ichthyocercus, Pleurotaenium, Tetmemorus, and Triploceras); three were new additions to the algal flora of Brazil (Haplotaenium minutum var. minutum f. maius, Ichthyocercus angolensis, and Pleurotaenium coronatum var. nodulosum). In addition, the geographical distributions of 20 taxa were expanded to include northeastern Brazil. The genus Docidium was reported for the first time in Bahia.
\end{abstract}

Key words: Continental algae, Streptophyta, Taxonomic inventory

\section{Introduction}

The family Desmidiaceae (Desmidiales, Zygnematophyceae) comprises unicellular organisms, some uniseriate with "filamentous" habits or, more rarely, colonial without any definite shape (Martins 1982; Acleto \& Zúñiga 1998; Yinxin \& Minjuan 2005; Graham et al. 2009). Although this family demonstrates significant species richness, comprising approximately $70 \%$ of the total number of known species of Zygnematophyceae (Gontcharov \& Melkonian 2005), those taxa are distributed non-uniformly among the 36 recognized genera.

Desmidiaceae are characterized by having cells that are circular, flattened, or angular when viewed vertically and have an accentuated median sinus (Kouwets \& Coesel 1984). Among the 36 genera that compose the Desmidiaceae, six have cylindrical and elongated morphologies: Docidium Bréb. ex Ralfs; Haplotaenium T.Bando; Ichthyocercus West \& G.S. West; Pleurotaenium Nägeli; Tetmemorus Ralfs ex Ralfs; and Triploceras J.W. Bailey. The last five of those have all appeared in studies undertaken in the state of Bahia, Brazil, by Förster (1964), Martins \& Bicudo (1987) and Bicudo \& Martins (1989), who collectively inventoried a total of 13 taxa.
With the goal of expanding knowledge of desmids in the state of Bahia, we conducted a taxonomic inventory of Desmidiaceae genera with cylindrical morphologies that occurring in three environmentally protected areas (EPAs) in the coastal plains of northern Bahia.

\section{Materials and methods}

This study was conducted within the Lagoas de Guarajuba EPA (230 ha), the Rio Capivara EPA (1800 ha), and the Litoral Norte EPA (144,000 ha), the exact locations of which are shown in Fig. 1.

During the summer months (January-March) and winter months (June-August) of two separate years (2007 and 2009), we collected a total of 90 samples: 30 from the Lagoas de Guarajuba EPA, 30 from the Rio Capivara EPA and 30 from the Litoral Norte EPA. The material was collected according to standard methodologies for taxonomic studies of microalgae (Bicudo \& Menezes 2006).

The metric characteristics of the populations were determined with an ocular micrometer; photomicrographs were taken with a digital camera coupled to an optical microscope; and the species identifications were based on the specialized literature.

\footnotetext{
${ }^{1}$ Universidade Estadual de Feira de Santana, Programa de Pós-Graduação em Botânica, Departamento de Ciências Biológicas, Laboratório de Ficologia, Feira de Santana, BA, Brazil

${ }^{2}$ Instituto de Botânica, Seção de Ecologia, São Paulo, SP, Brazil

${ }^{3}$ Author for correspondence: ivboliveira@gmail.com
} 


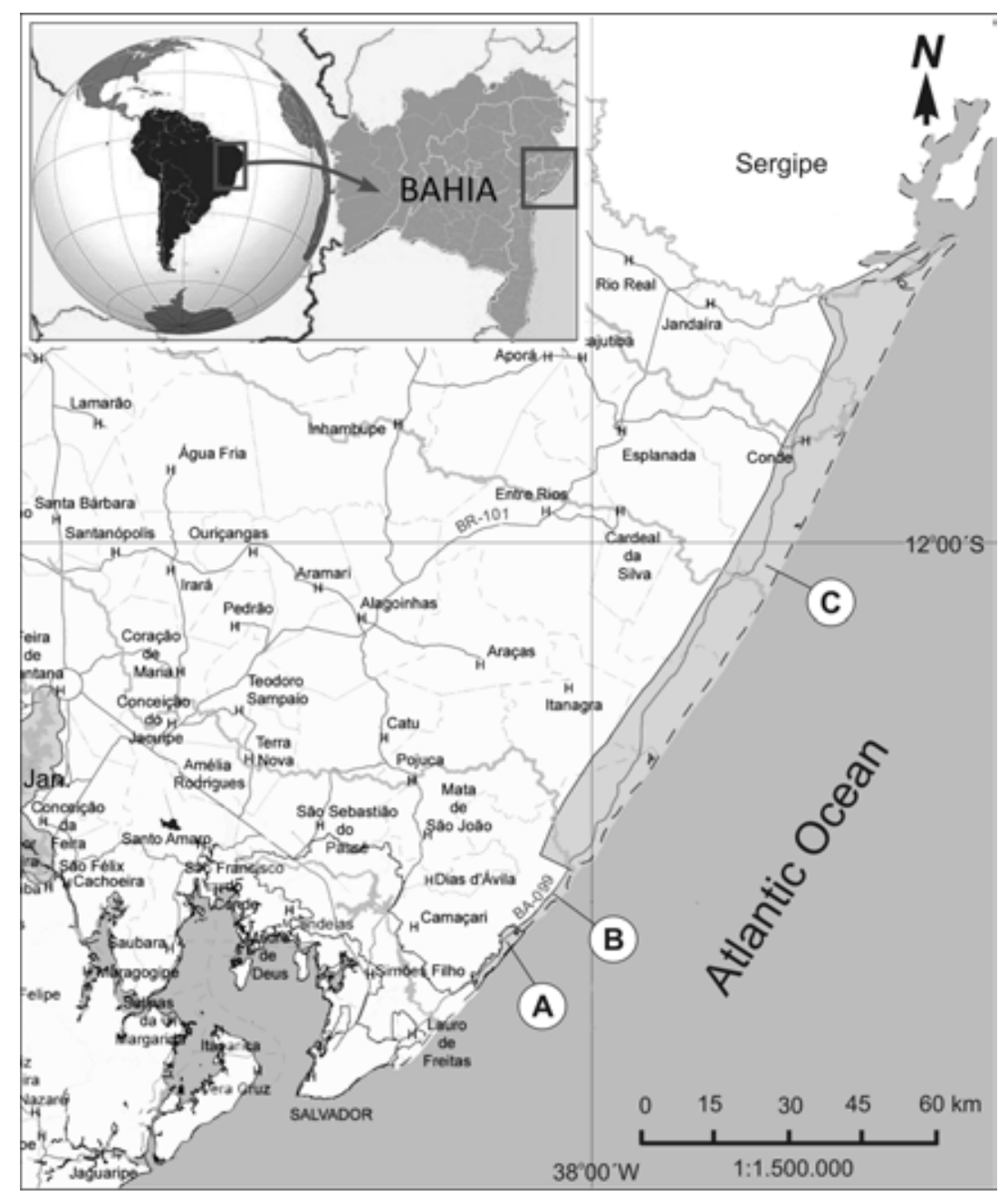

Figure 1. Map of the state of Bahia and its environmentally protected areas: A. Rio Capivara, B. Lagoas de Guarajuba, C. Litoral Norte.

Based on Oliveira et al. (2011).

The samples were preserved in Transeau's solution (prepared according to Bicudo \& Menezes 2006), and subsequently incorporated into the liquid collection of the Herbarium of the (Bahia) State University of Feira de Santana (code, HUEFS).

\section{Results and discussion}

The analyses of the 90 samples resulted in the identification of 32 taxa belonging to six genera: Docidium, Haplotaenium, Ichthyocercus, Pleurotaenium, Tetmemorus and Triploceras.

Docidium Bréb. ex Ralfs, 1848

Docidium baculum Bréb. ex Ralfs var. baculum, Brit. Dem.: 158, pl. 33, fig. 5. 1848.

Fig. 2-3

Cells ca. 23-27 times longer than wide (215-330 $\mu \mathrm{m}$ long by $12.5-15 \mu \mathrm{m}$ wide), isthmus $10-11 \mu \mathrm{m}$ wide, apex 7-9 $\mu \mathrm{m}$ wide, outline cylindrical, median constriction shallow, poorly defined, median sinus open, isthmus region marked by pleats, lateral margins retuse, parallel, apical margins smooth, rounded; cell walls hyaline, smooth; chloroplast axial, laminar, 2-8 axial pyrenoids.

Distribution in Brazil: Amazonas (Förster 1969); Goiás (Förster 1964).

Material selected: Brazil. Bahia: Conde, APA Litoral Norte, 01/III/2009, Oliveira \& Moura s.n. (HUEFS 155658, HUEFS 155660), 11/VII/2009, Oliveira et al. s.n. (HUEFS 155720); Entre Rios, APA Litoral Norte, 26/VII/2009, Oliveira \& Farias s.n. (HUEFS 155748, HUEFS 155754); Mata de São João, APA Litoral Norte, 14/III/2009, Oliveira \& Moura s.n. (HUEFS 155706).

Docidium baculum var. baculum can be identified relatively easily due to its distinct morphological characters with taxonomic value, such as the pleats in the isthmus region and the smooth, rounded apical margins. 
Haplotaenium T.Bando, 1988

Haplotaenium minutum (Ralfs) T. Bando var. minutum f. minutum, J. Jap. Bot. 63: 176. 1988.

Docidium minutum Ralfs, Brit. Desm.: 158, pl. 26, fig. 5. 1848. Fig. 4-9

Cells ca. 11-12 times longer than wide (150-225 $\mu \mathrm{m}$ long by $12.5-20 \mu \mathrm{m}$ wide), isthmus 11-17.5 $\mu \mathrm{m}$ wide, apex 9-16 $\mu \mathrm{m}$ wide, outline cylindrical, median constriction shallow, poorly defined, median sinus open, lateral margins retuse, parallel, apical margins rounded; cell walls hyaline, smooth; chloroplast axial, laminar, 2-8 axial pyrenoids.

Distribution in Brazil: Amazonas (Förster 1974; Martins 1982); Bahia (Martins \& Bicudo 1987; Bicudo \& Martins 1989); Goiás (Förster 1964); Mato Grosso (Borge 1925); Mato Grosso do Sul (Borge 1903; Sophia et al. 2005); Pará (Grönblad 1945; Scott et al. 1965); São Paulo (Borge 1918; Azevedo 1984; Bicudo et al. 1998).

Material selected: Brazil. Bahia: Camaçari, APA Lagoas de Guarajuba, 12/I/2007, Oliveira \& Oliveira s.n. (HUEFS 125504); APA Rio Capivara, 12/I/2007, Oliveira et al. s.n. (HUEFS 125547, HUEFS 125550); Esplanada, APA Litoral Norte, 14/II/2009, Oliveira \& Moura s.n. (HUEFS 155614), 12/VII/2009, Oliveira et al. s.n. (HUEFS 155724, HUEFS 155725); Entre Rios, APA Litoral Norte, 26/VII/2009, Oliveira \& Farias s.n. (HUEFS 155776, HUEFS 155779).

Morphologically, H. minutum var. minutum f. minutum is very similar to Pleurotaenium trabecula (Ralfs) Delponte var. rectum (Delponte) West \& G.S.West, although the latter differs by having more well-developed basal intumescence and ribbon-shaped chloroplasts.

In the material examined, we noted variations in the shapes of the apices, which were either rounded or truncated (Fig. 5 and 8), and in the basal intumescence, which was either conspicuous or inconspicuous (Fig. 6 and 9).

Haplotaenium minutum (Ralfs) T.Bando var. cylindricum (Borge) H.Krieg. In Rabenhorst, Kryptogamen-Fl. Deutschl. 13: 393, pl. 39, fig. 8. 1937.

Penium cylindricum Borge, Ark. Bot. 1: 75, pl. 1, fig. 5. 1903. Fig. 12

Cells ca. 12-15 times longer than wide (145-260 $\mu \mathrm{m}$ long by $12-18 \mu \mathrm{m}$ wide), isthmus $11-16 \mu \mathrm{m}$ wide, outline cylindrical, median constriction shallow, poorly defined, median sinus open, lateral margins retuse, parallel, apical margins rounded; cell walls hyaline, smooth; chloroplast axial, laminar, 2-8 axial pyrenoids.

Distribution in Brazil: Amazonas (Förster 1969).

Material selected: Brazil. Bahia: Camaçari, APA Lagoas de Guarajuba, 09/III/2007, Oliveira et al. s.n. (HUEFS 125527, HUEFS 125537); APA Rio Capivara, 25/VIII/2007, Oliveira et al. s.n. (HUEFS 125590, HUEFS 125606); Mata de São João, APA Litoral Norte, 11/I/2009, Oliveira \& Moura s.n. (HUEFS 155598, HUEFS 155602), 15/II/2009, Oliveira \& Farias s.n. (HUEFS 155625, HUEFS 155634); Esplanada, APA Litoral Norte, 28/II/2009, Oliveira \& Farias s.n. (HUE-
FS 155641); Entre Rios, APA Litoral Norte, 26/VII/2009, (HUEFS 155748, HUEFS 155760).

The specimens analyzed coincided with the original description proposed by Borge (1903). That author described and illustrated the taxon from material collected in the state of Rio Grande do Sul as Penium cylindricum Borge.

The variety cylindricum differs from the typical variety of the species by having perfectly cylindrical cells and an almost imperceptible median swelling.

Haplotaenium minutum (Ralfs) T.Bando var. crassum (West) H.Krieg. f. crassum, Arch. Hydrobiol., suppl. 11: 67, pl. 6, fig. 8. 1932.

Penium minutum (Ralfs) Cleve var. crassum West, Journ. Linn. Soc. Bot. 29(199-200): 130, pl. 20, fig. 1. 1892.

Fig. 10-11

Cells ca. 4.6-5.1 times longer than wide (70-77 $\mu \mathrm{m}$ long by 15-16.5 $\mu \mathrm{m}$ wide), isthmus 11-13 $\mu \mathrm{m}$ wide, outline approximately cylindrical, median constriction shallow, median sinus open, lateral margins retuse, parallel, apical margins rounded, apex truncated; cell walls hyaline, smooth; chloroplast axial, laminar, 2-4 axial pyrenoids.

Distribution in Brazil: Amazonas (Förster 1969; 1974); Bahia (Martins \& Bicudo 1987); Goiás (Förster 1964); Pará (Scott et al. 1965).

Material selected: Brazil. Bahia: Camaçari, APA Lagoas de Guarajuba, 09/III/2007, Oliveira et al. s.n. (HUEFS 125528, HUEFS 125534); APA Rio Capivara, 08/VI/2007, Oliveira et al. s.n. (HUEFS 125563); Mata de São João, APA Litoral Norte, 11/I/2009, Oliveira \& Moura s.n. (HUEFS 155599, HUEFS 155610), 14/III/2009, Oliveira \& Moura s.n. (HUEFS 155687); Esplanada, APA Litoral Norte, 28/II/2009, Oliveira \& Farias s.n. (HUEFS 155641); Entre Rios, APA Litoral Norte, 26/VII/2009, (HUEFS 155752).

The variety crassum differs from the typical variety of the species by having cells that are proportionately shorter and 4.9-5.8 times longer than their maximum diameter. Azevedo (1984) noted the morphological similarities of this taxon to Actinotaenium comissulare (de Bary) Teiling and to Pleurotaenium minutum (Ralfs) Delponte var. crassum (West \& G.S.West) H.Krieg. f. crassum (=Haplotaenium minutum var. crassum f. crassum), because both show semicells whose lateral margins are parallel to each other or slightly swollen, have smooth or finely punctuated cell walls and contain a narrow axial chloroplast, the apical views of the cells being circular.

Haplotaenium minutum (Ralfs) T. Bando var. excavatum (Scott \& Grönblad) T.Bando

J. Jap. Bot. 63: 176. 1988.

Pleurotaenium minutum Ralfs var. excavatum A.M. Scott \& Grönblad, Acta Soc. Sc. Fenn.: sér. B, 2(8): 11, pl. 2, fig. 3-4. 1957.

Fig. 13-15

Cells ca. 29.5-31 times longer than wide (280-340 $\mu \mathrm{m}$ long by $9.5-11 \mu \mathrm{m}$ wide), apex $9.5 \mu \mathrm{m}$ wide, outline cylin- 
drical, median constriction shallow, poorly defined, median sinus open, lateral margins retuse, parallel, apical margins hollowed, angles acute; cell walls hyaline, smooth; chloroplast axial, laminar, 2-8 pyrenoids in axial series.

Distribution in Brazil: Pará (Förster 1969); São Paulo (Azevedo 1984).

Material selected: Brazil. Bahia: Mata de São João, APA Litoral Norte, 11/1/2009, Oliveira \& Moura s.n. (HUEFS 155603), 14/II/2009, Oliveira \& Moura s.n. (HUEFS 155614), 14/III/2009, Oliveira \& Farias s.n. (HUEFS 155703), Esplanada, APA Litoral Norte, 28/II/2009, Oliveira \& Farias s.n. (HUEFS 155731); Entre Rios, APA Litoral Norte, 26/VII/2009, (HUEFS 155785).

Haplotaenium minutum var. excavatum differs from the typical variety of the species by having a hollow apex, acute apical angles, and cells that are approximately 30 times longer than they are wide. Morphologically, the taxon is similar to Pleurotaenium minutum var. bourrellyi Grönblad \& Scott, although the latter differs by having a retuse apex and rounded angles. The variety excavatum also somewhat resembles the variety longissimum Scott \& Grönblad, although the latter differs by having proportionally larger cells, an inflated apex and thick cell walls.

Haplotaenium minutum (Ralfs) T.Bando var. gracile (Wille) T.Bando, J. Jap. Bot. 63: 176. 1988.

Penium minutum var. gracile Wille. Forh. Vidensk.-Selsk. Christiania 1880 (11): 51, pl. II: fig. 33. 1880.

Fig. 16-17

Cells ca. 18-19 times longer than wide (180-210 $\mu \mathrm{m}$ long by 10-11 $\mu \mathrm{m}$ wide), isthmus 9-10 $\mu \mathrm{m}$ wide, apex 9-10 $\mu \mathrm{m}$ wide, outline cylindrical, median constriction shallow, poorly defined, median sinus open, lateral margins retuse, parallel, apical margins rounded; cell walls hyaline, smooth; chloroplast axial, laminar, 2-8 axial pyrenoids.

Distribution in Brazil: Amazonas (Förster 1969); Goiás (Förster 1964); Pará (Scott et al. 1965); Rio Grande do Sul (Sophia et al. 2005).

Material selected: Brazil. Bahia: Conde, APA Litoral Norte, 02/VIII/2009, Oliveira \& Moura s.n. (HUEFS 155802, HUEFS 155819); Esplanada, APA Litoral Norte, 14/II/2009, Oliveira \& Farias s.n. (HUEFS 155614), 12/VII/2009, Oliveira et al. s.n. (HUEFS 155724).

Haplotaenium minutum var. gracile differs from the typical variety of the species by having slender cells, up to 20 times longer than they are wide, slight (almost imperceptible) basal swelling and rounded apical margins.

Haplotaenium minutum (Ralfs) T. Bando var. latum (Kaiser) T. Bando, J. Jap. Bot. 63: 176. 1988.

Pleurotaenium minutum (Ralfs) Delponte var. latum Kaiser, Krypt. Forsch. 2: 125. 1931.

Fig. 18

Cells ca. 9-10 times longer than wide (175-225 $\mu \mathrm{m}$ long by $19-23 \mu \mathrm{m}$ wide), isthmus $15-19 \mu \mathrm{m}$ wide, apex 14-17.5 $\mu \mathrm{m}$ wide, outline cylindrical, median constriction shallow, median sinus open, lateral margins slightly swollen, apical margins truncated, angles rounded; cell walls hyaline, smooth; chloroplast axial, laminar, 2-8 axial pyrenoids.

Distribution in Brazil: Amazonas (Thomasson 1971); São Paulo (Azevedo 1984).

Material selected: Brazil. Bahia: Esplanada, APA Litoral Norte, 12/VII/2009, Oliveira et al. s.n.(HUEFS 155724, HUEFS 155725); Entre Rios, APA Litoral Norte, 26/ VII/2009, Oliveira \& Farias s.n. (HUEFS 155741).

Haplotaenium minutum var. latum differs from the typical variety of the species by having cells that are generally wider, with minimal swelling in the isthmus region and an apex that is truncated with rounded angles.

Morphologically, the taxon is similar to the variety cylindricum (Borge) Krieger and the variety bourrellyi Grönblad \& Scott, both of the same species. It differs from the former by having perfectly cylindrical semicell margins, rounded apices and minimal basal swelling, whereas it differs from the latter by having apical margins that show slight depressions and semicells with parallel lateral margins.

Haplotaenium minutum (Ralfs) Delponte var. minutum $\mathrm{f}$. maius (P. Lundell) Kossinsk.

Flora Plant. Crypt. URSS 5(2): 279, pl. 33, fig. 10. 1960. Penium minutum (Ralfs) Cleve f. maius P. Lundell, Nova Acta R. Soc. Scient. Upsala: sér. 3, 8: 87. 1871.

Fig. 19

Cells ca. 16-20 times longer than wide (150-240 $\mu \mathrm{m}$ long by $8-14.5 \mu \mathrm{m}$ wide), apex 7.5-11 $\mu \mathrm{m}$ wide, isthmus 8-12.5 $\mu \mathrm{m}$ wide, outline approximately cylindrical, median constriction shallow, open; lateral margins parallel to each other, slightly attenuated, apical margins rounded, truncated, smooth, angles rounded; cell walls hyaline, smooth; chloroplast axial, irregular, multiple pyrenoids in series.

Distribution in Brazil: Bahia (this study).

Material selected: Brazil. Bahia: Camaçari, APA Lagoas de Guarajuba, 09/III/2007, Oliveira et al. s.n. (HUEFS 125529), 20/VII/2007, Oliveira et al. s.n. (HUEFS 125597); APA Rio Capivara, 12/I/2007, Oliveira \& Oliveira s.n. (HUEFS 125515), 08/VI/2007, Oliveira et al. s.n. (HUEFS 125570); Mata de São João, APA Litoral Norte, 11/I/2009, Oliveira \& Moura s.n. (HUEFS 155603), 14/III/2009, Oliveira \& Moura s.n. (HUEFS 155703), Esplanada, APA Litoral Norte, 28/ II/2009, Oliveira \& Farias s.n. (HUEFS 155641); Entre Rios, APA Litoral Norte, 26/VII/2009, Oliveira et al. s.n. (HUEFS 155785); Conde, APA Litoral Norte, 02/VIII/2009, Oliveira \& Moura s.n. (HUEFS 155802, HUEFS 155819).

The variety maius differs from the typical variety of the species by having a greater length to width ratio, the cells being 7 to 12 times longer than they are wide.

Morphologically, Haplotaenium minutum var. minutum f. maius is similar to H. minutum var. gracile (Wille) H.Krieg., although the former shows no basal swelling immediately below the isthmus. 

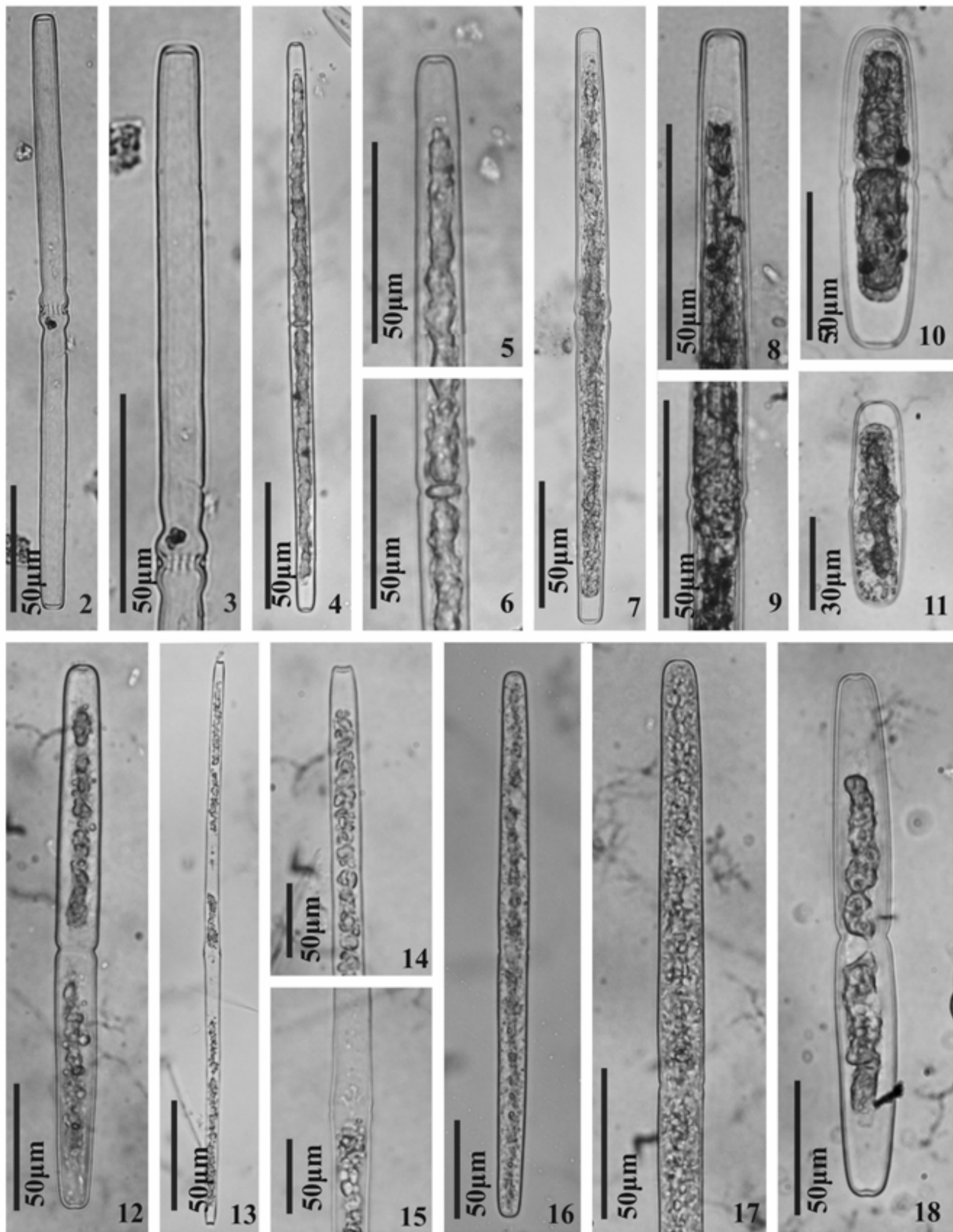

6
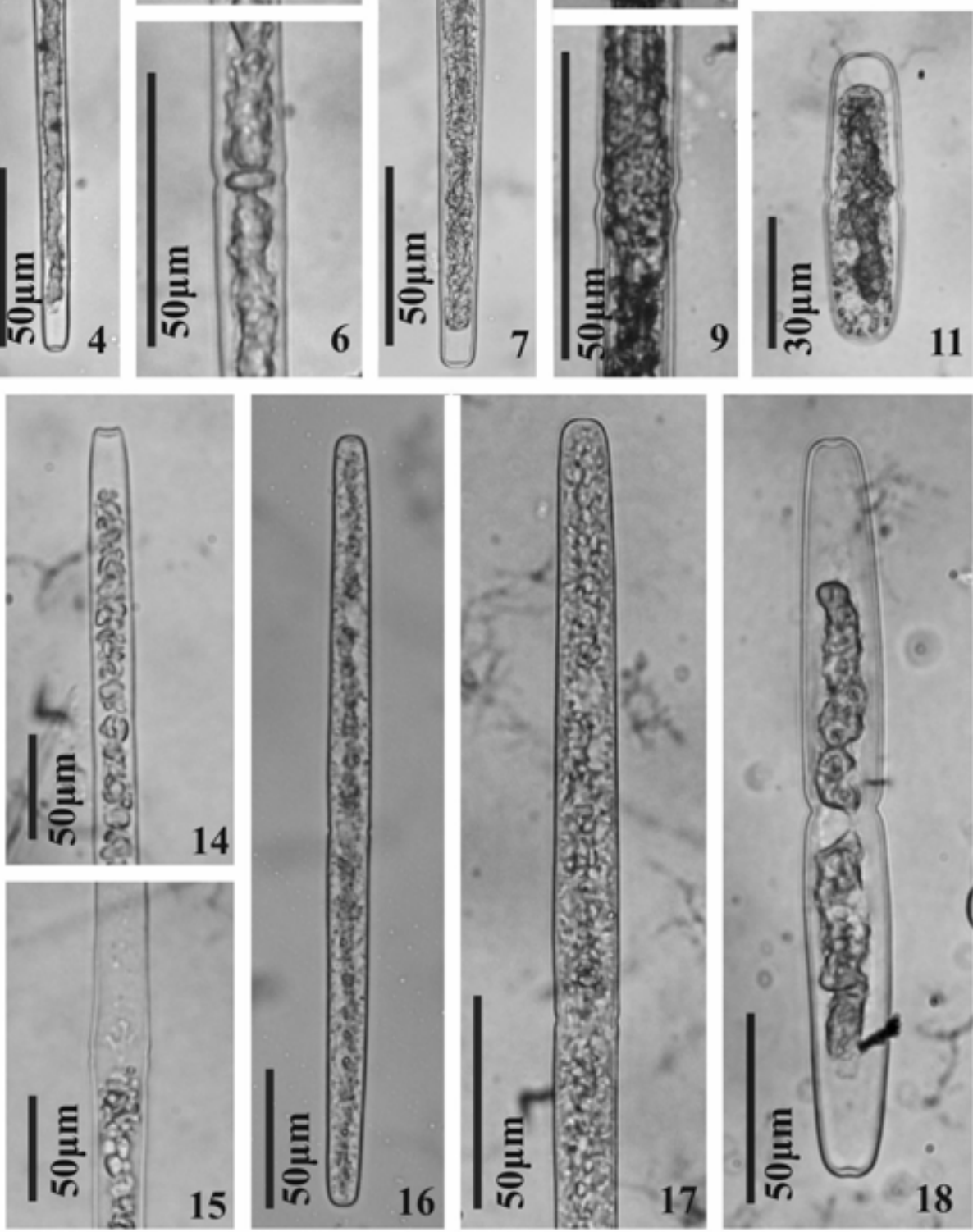

Figures 2-18. Fig. 2 and 3. Docidium baculum Bréb. ex Ralfs var. baculum: 3. Detail of the apex and isthmus; Fig. 4-9. Haplotaenium minutum (Ralfs) T. Bando var. minutum f. minutum: 5 and 8. Detail of the apex, 6 and 9. Detail of the isthmus; Fig. 10, 11. Haplotaenium minutum var. crassum (West) Willi Krieg. f. crassum Fig. 12. Haplotaenium minutum var. cylindricum (Borge) Willi Krieg.; Fig. 13-15. Haplotaenium minutum var. excavatum (A.M. Scott \& Grönblad) T. Bando; Fig. 16 and 17. Haplotaenium minutum var. gracile (Wille) T. Bando: 17. Detail of the apex and isthmus; Fig. 18. Haplotaenium minutum var. latum (Kaiser) T.Bando. 
The material studied here coincided with the specimens described and illustrated in the works of Prescott et al. (1975) and Růžička (1977, as Pleurotaenium minutum var. minutum f. minutum).

Haplotaenium rectum (Delponte) T.Bando var. rectum, J. Jap. Bot. 63: 176. 1988.

Pleurotaenium rectum Delponte, Mem. R. Acad. Sci. Torino: sér. 2, 30: 129, pl. 20, fig. 8-11. 1878.

Fig. 20-22

Cells ca. 16-17 times longer than wide (220-256 $\mu \mathrm{m}$ long by $13.5-15 \mu \mathrm{m}$ wide), isthmus $11-13 \mu \mathrm{m}$ wide, apex $9-10 \mu \mathrm{m}$ wide, median constriction shallow, poorly defined, median sinus open, lateral margins retuse, parallel, apical margins rounded; cell walls hyaline, smooth; chloroplast axial, 2-8 axial pyrenoids.

Distribution in Brazil: Amazonas (Förster 1969; 1974); Rio de Janeiro (Sophia 1991).

Material selected: Brazil. Bahia: Esplanada, APA Litoral Norte, 28/II/2009, Oliveira \& Farias s.n. (HUEFS 155641); Mata de São João, APA Litoral Norte, 14/III/2009, Oliveira \& Moura s.n. (HUEFS 155703).

Haplotaenium rectum differs from the typical variety of the species simply by having an inconspicuous (almost imperceptible) median swelling.

\section{Ichthyocercus West \& G.S.West, 1897}

Ichthyocercus angolensis West \& G.S.West, Jour. Lin. Soc. Bot. 33: pl. 10, fig. 10. 1897.

Fig. 23-26

Cells 2.5-2.8 times longer than wide, not considering the angular spines (45-60 $\mu \mathrm{m}$ and 40-55 $\mu \mathrm{m}$ long with and without spines, respectively, by $15-20 \mu \mathrm{m}$ wide), isthmus 12.5-15 $\mu \mathrm{m}$ wide, median constriction shallow, sinus open, semicells slightly twisted in the isthmus region; semicells cylindrical, lateral margins slightly swollen, apical margins convex, angles ornamented with a single, sharp robust spine; cell walls hyaline, punctuated; two axial chloroplasts.

Distribution in Brazil: Bahia (this study).

Material selected: Brazil. Bahia: Mata de São João, APA Litoral Norte, 14/III/2009, Oliveira \& Moura s.n. (HUEFS 155703); Entre Rios, APA Litoral Norte, 26/VII/2009, Oliveira et al. s.n. (HUEFS 155748).

In terms of its morphology, Ichthyocercus angolensis can be compared to I. longispinus (Borge) Willi Krieg. var. tinhareensis D. Martins \& C.E.M. Bicudo, although the latter differs by having proportionally smaller spine angles and spines with a shorter lateral projection.

Pleurotaenium Nägeli emend. Grönblad 1924

Pleurotaenium caldense Nordst. var. cristatum (W.B.Turner) H.Krieg., In Rabenhorst, Kryptogamen-Fl. Deutschl. 13(1): 425, pl. 46, fig. 2. 1937.

Docidium cristatum W.B.Turner, K. svenska VetenskAkad. Handl. 25(5): 32, pl. 4, fig. 7. 1892.

Fig. 27-29
Cells ca. 16-17 times longer than wide (470-550 $\mu \mathrm{m}$ long by $29-34 \mu \mathrm{m}$ wide), apex $25-31 \mu \mathrm{m}$ wide, isthmus $23-29$ $\mu \mathrm{m}$ wide, outline cylindrical, median constriction shallow, angles rounded; lateral margins straight, parallel to each other with a single conspicuous basal intumescence; apex inflated, bordered by a single crown of globose granules, 16-18 visible in frontal view; cell walls hyaline to yellowishbrown, coarsely punctuated; chloroplasts parietal, ribbonlike, multiple pyrenoids.

Distribution in Brazil: São Paulo (Azevedo 1984; Bicudo et al. 1998).

Material selected: Brazil. Bahia: Camaçari, APA Lagoas de Guarajuba, 12/I/2007, Oliveira \& Oliveira s.n. (HUEFS 125503), 09/III/2007, Oliveira et al. s.n. (HUEFS 125529); APA Rio Capivara, 08/VI/2007, Oliveira \& Oliveira s.n. (HUEFS 125567); Mata de São João, APA Litoral Norte, 11/I/2009, Oliveira \& Moura s.n. (HUEFS 155598, HUEFS 155599); Esplanada, APA Litoral Norte, 14/I//2009, Oliveira \& Moura s.n. (HUEFS 155614), 28/II/2009, Oliveira \& Farias s.n. (HUEFS 155641).

The variety cristatum differs from the typical variety of the species by having semicells with smooth lateral margins, having no undulations above the basal intumescence and cells that are 16-17 times longer than they are wide.

Pleurotaenium caldense Nordst. var. cristatum is morphologically identical to P. subcoronulatum (W.B.Turner) West \& G.S.West var. africanum (Schmidle) H.Krieg., except for the fact that the cells of the former are always isolated and solitary, whereas those of the latter are linked pole to pole, forming false filaments, as the cells are only juxtaposed and therefore easily dissociated (Prescott $e t$ al. 1975; Azevedo 1984),

Pleurotaenium coronatum (Bréb.) Rabenh. var. coronatum, Fl. Europ. Alg.: 143. 1868.

Docidium coronatum Bréb. In Ralfs,1848, Brit. Desm.: 217, pl. XXXV: fig. 6. 1848.

Fig. 30-32

Cells cylindrical, ca. 9-10 times longer than wide (310$440 \mu \mathrm{m}$ long by $31-42.51 \mu \mathrm{m}$ wide), apex $27.5-38 \mu \mathrm{m}$ wide, isthmus $28-32 \mu \mathrm{m}$ wide, median constriction shallow, median sinus shallow, isthmus marked by a thickened, brownish ring; semicells approximately cylindrical, lateral margins parallel to each other, slightly convergent in the direction of the apex, 3-4 slight undulations just beyond the basal intumescence. Apical margins straight, decorated with a single ring composed of 4-6 conical granules, widely spaced; cell walls hyaline to slightly brownish, scrobiculate; chloroplasts parietal, ribbon-like, multiple pyrenoids.

Distribution in Brazil: Bahia (this study).

Material selected: Brazil. Bahia: Mata de São João, APA Litoral Norte, 11/I/2009, Oliveira \& Moura s.n. (HUEFS 155599); Entre Rios, APA Litoral Norte, 26/VII/2009, Oliveira et al. s.n. (HUEFS 155641), Conde, APA Litoral Norte, 02/VIII/2009, Oliveira \& Moura s.n. (HUEFS 155819). 
From a morphological point of view, Pleurotaenium coronatum var. coronatum is similar to P. ehrenbergii (Bréb.) De Bary var. undulatum Schaarschm., although the latter differs by having cells that are proportionally larger and are up to 23 times longer than they are wide, with notably undulating lateral margins and apical margins that are rounded and ornamented with round granules.

Pleurotaenium coronatum (Bréb.) Rabenh. var. nodulosum (Bréb.) West, Journ. Linn. Soc. Bot. 29(199-200): 119. 1892. Docidium nodulosum Bréb. in Ralfs, Brit. Desm. 155, pl. 26, fig. 1. 1848.

Fig. 33-35

Cells ca. 11 times longer than wide (400-480 $\mu \mathrm{m}$ long by $35-41 \mu \mathrm{m}$ wide), apex $28-32 \mu \mathrm{m}$ wide, isthmus $28-32$ $\mu \mathrm{m}$ wide, median constriction shallow, sinus short, isthmus marked by a thickened ring, lateral margins slightly convergent towards the apex, 3-4 undulations just beyond the basal intumescence, apical margins straight, decorated with a single ring composed of 4-5 widely spaced conical granules; cell walls hyaline to yellowish, delicately punctuated; chloroplasts parietal, ribbon-like, multiple pyrenoids. Distribution in Brazil: Bahia (this study).

Material selected: Brazil. Bahia: Camaçari, APA Lagoas de Guarajuba, 20/VII/2007, Oliveira \& Oliveira s.n. (HUEFS 125597); APA Rio Capivara, 20/VII/2007, Oliveira \& Oliveira s.n. (HUEFS 125589); Mata de São João, APA Litoral Norte,11/I/2009, Oliveira \& Moura s.n. (HUEFS 155603), Esplanada, APA Litoral Norte,14/II/2009, Oliveira \& Farias s.n. (HUEFS 155612); Entre Rios, APA Litoral Norte, 26/ VII/2009, Oliveira et al. s.n. (HUEFS 155741); Conde, APA Litoral Norte,02/VIII/2009, Oliveira \& Moura s.n. (HUEFS 155819).

Pleurotaenium coronatum (Bréb.) Rabenh. var. nodulusum (Bréb.) West differs from the typical variety of the species by having lateral margins that gradually narrow towards the apex, with quadrangular apical angles, prominent basal swelling and scrobiculate cell walls.

This species is morphologically similar to Pleurotaenium coronatum var. robustum West, the latter differing by having relatively wider cells and consequently a lower cell length/ width ratio, the cells being approximately 8 times longer than they are wide, and the lateral margins showing uniform undulations from the base to the apex.

The populations examined in the study area were coincident with the descriptions and illustrations presented in the works of West \& West (1904) and Prescott et al. (1975).

Pleurotaenium coroniferum (Borge) Willi Krieg. var. coroniferum, In Eabenh., Kryptog.Fl. Deutschl. 13(1): 422, pl. 45, fig. 9. 1937.

Pleurotaenium subundulatum Borge var. coroniferum Borge, Ark. Bot. 1: 84, pl. 2, fig. 9. 1903.

Fig. 36-38

Cells ca. 10-12 times longer than wide (355-440 $\mu \mathrm{m}$ long by $35-37.5 \mu \mathrm{m}$ wide), apex $25-26 \mu \mathrm{m}$ wide, isthmus $24-25$ $\mu \mathrm{m}$ wide, outline cylindrical, median constriction shallow, angles rounded; lateral margins undulating, with five conspicuous intumescences, bordered by a crown of 5-6 globose granules; cell walls hyaline to yellowish-brown; chloroplasts parietal, ribbon-like, multiple pyrenoids.

Distribution in Brazil: Mato Grosso (Borge 1925).

Material selected: Brazil. Bahia: Entre Rios, APA Litoral Norte, 26/VII/2009, Oliveira et al. s.n. (HUEFS 155748); Conde, APA Litoral Norte, 02/VIII/2009, Oliveira \& Moura s.n. (HUEFS 155819).

Morphologically, Pleurotaenium coroniferum is similar to $P$. constrictum (Bailey) Wood var. constrictum, although the latter differs by having four large undulations of equal size in each semicell and an apex with 4-5 conical tubercles.

Pleurotaenium ehrenbergii (Bréb. ex Ralfs) Delponte var. ehrenbergii, Conjugate. 75, 1858.

Docidium ehrenbergii Bréb., In Brit. Desm.: 157, pl. 26, fig. 4. 1848.

Fig. 39-41

Cells ca. 17-18 times longer than wide (400-450 $\mu \mathrm{m}$ long by $24-25 \mu \mathrm{m}$ wide), apex $22.5-24 \mu \mathrm{m}$ wide, isthmus $22-23.5$ $\mu \mathrm{m}$ wide, median constriction shallow, lateral margins slightly undulating above median swelling; apex bordered by granules; cell walls hyaline, punctuated; apical view circular, capitulate; lateral and frontal views identical; chloroplasts ribbon-like, multiple; pyrenoids multiple.

Distribution in Brazil: Amazonas (Lopes \& Bicudo 2002); Mato Grosso (Borge 1925; Camargo et al. 2009); Pará (Scott et al. 1965; Förster 1969; Thomasson 1971); Paraná (Rodrigues \& Bicudo 2001; Cetto et al. 2004; Felisberto \& Rodrigues 2008; Biolo et al. 2008); Rio de Janeiro (Sophia 1999); Rio Grande do Sul (Ungaretti 1981); São Paulo (Borge 1918; Bicudo 1969; Azevedo 1984; Bicudo et al. 1998; Ferragut et al. 2005).

Material selected: Brazil. Bahia: Mata de São João, APA Litoral Norte, 11/I/2009, Oliveira \& Moura s.n. (HUEFS 155610); Esplanada, APA Litoral Norte, 14/II/2009, Oliveira \& Moura s.n. (HUEFS 155613), 28/II/2009, Oliveira \& Farias s.n. (HUEFS 155641); Conde, 11/VII/2009, Oliveira \& Moura s.n. (HUEFS 155720).

Slight variations in the numbers of undulations above the basal intumescence on the lateral margins of the semicells were noted, being more apparent in some specimens than in others (Fig. 41).

Azevedo (1984) noted that these undulations could vary from none to five, and because these variations could be seen even in the semicells of a single individual, they would have no taxonomic value.

Pleurotaenium ehrenbergii (Bréb. ex Ralfs) Delponte var. elongatum West, Jour. Linn. Soc. Bot. 29(199-200): 119. 1892.

Docidium ehrenbergii Bréb. Dict. Univ. Hist. Nat. 5: 93. 1845. Fig. 42-44 

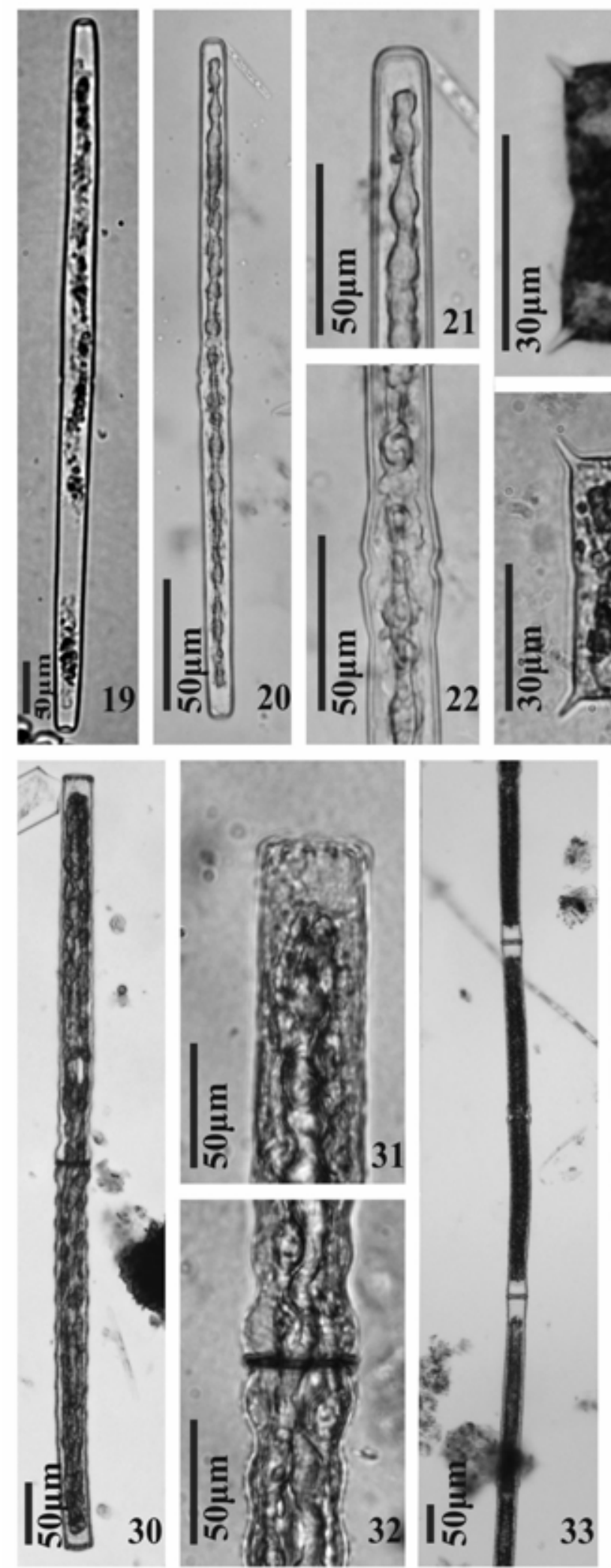
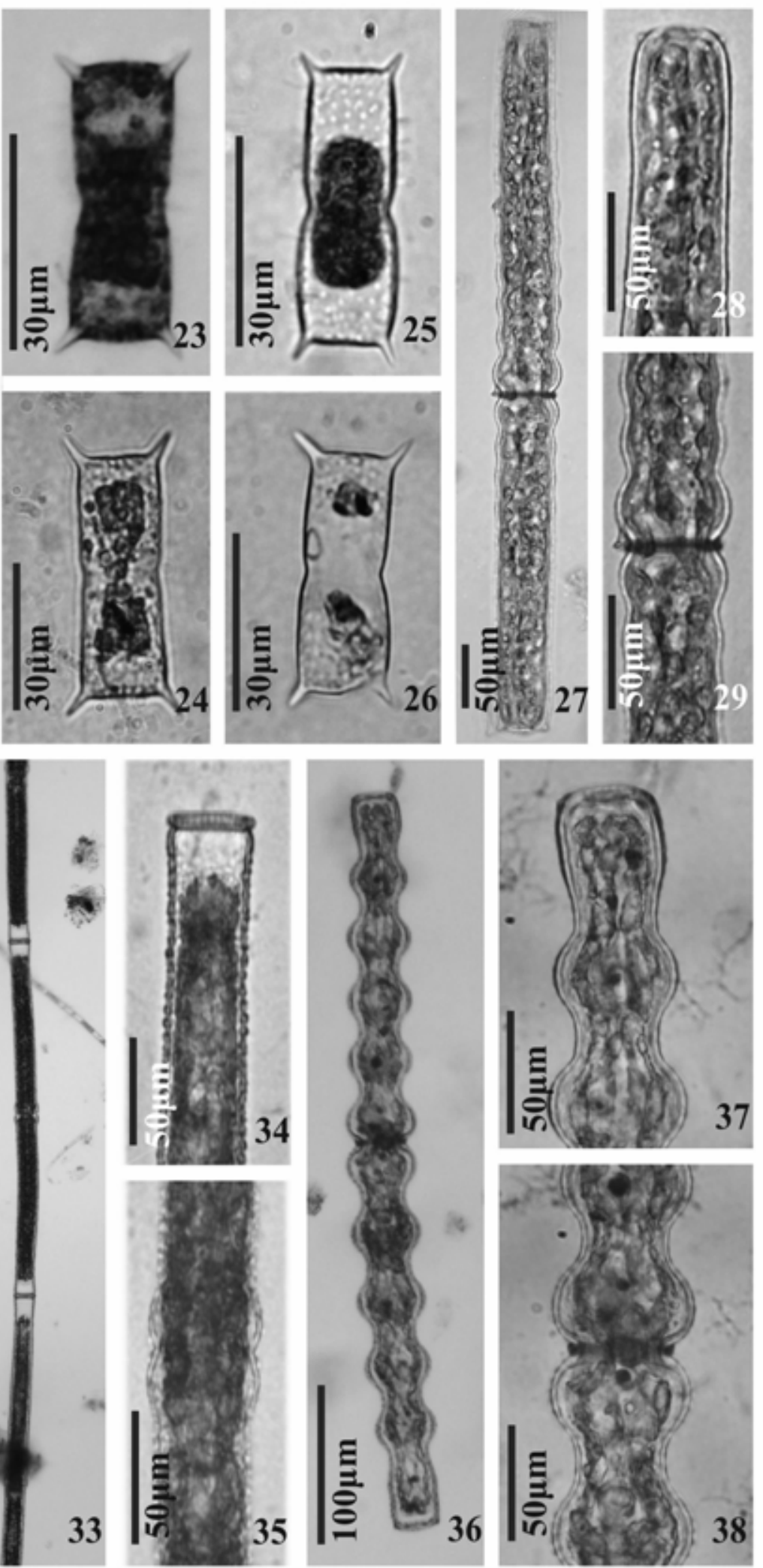

Figures 19-38. Fig. 19. Haplotaenium minutum (Ralfs) Delponte var. minutum f. maius (P. Lundell) Kossinsk; Fig. 20-22. H. rectum (Delponte) T. Bando var. rectum: 21. Detail of the apex, 22. Detail of the isthmus; Fig. 23-26. Ichthyocercus angolensis West \& G.S. West; Fig. 27-29. Pleurotaenium caldense Nordst. var. cristatum (W.B.Turner) Wili Krieg.; Fig. 30-32. Pleurotaenium coronatum (Bréb.) Rabenh. var. coronatum: 31. Detail of the apex, 32. Detail of the isthmus; Fig. 33-35. Pleurotaenium coronatum (Bréb.) Rabenh. var. nodulosum (Bréb) West: 34. Detail of the apex, 35. Detail of the isthmus; Fig. 36-38. Pleurotaenium coroniferum (Botgr) Willi Krieg. var. coroniferum: 37 . Detail of the apex, 38. Detail of the isthmus. 
Cells ca. 20-22 times longer than wide (700-780 $\mu \mathrm{m}$ long by $32-36 \mu \mathrm{m}$ wide), apex $30-34 \mu \mathrm{m}$ wide, isthmus $27.5-30 \mu \mathrm{m}$ wide, median constriction shallow, lateral margins smooth, slight median swelling; apex with a single group of granules in frontal view; cell walls hyaline, punctuated; apical view circular, capitulate; lateral view identical to frontal; chloroplasts axial; pyrenoids multiple.

Distribution in Brazil: Amazonas (Förster 1963; 1969); Bahia (Bicudo \& Martins 1989); Paraná (Felisberto \& Rodrigues 2008); São Paulo (Azevedo 1984).

Material selected: Brazil. Bahia: Conde, APA Litoral Norte, 11/VII/2009, Oliveira et al. s.n. (HUEFS 155720), 02/ VIII/2009, Entre Rios, APA Litoral Norte, 26/VII/2009, Oliveira et al. s.n. (HUEFS 155742); Mata de São João, APA Litoral Norte, 11/I/2009, Oliveira \& Moura s.n. (HUEFS 155603), 14/III/2009, Oliveira \& Moura s.n. (HUEFS 155703), Esplanada, APA Litoral Norte, 28/II/2009, Oliveira \& Farias s.n. (HUEFS 155641).

Pleurotaenium ehrenbergii var. elongatum is morphologically quite similar to the typical variety of the species, differing only by having slender cells that are more than 20 times longer than they are wide.

Irénée-Marie (1954) described the chloroplasts of this taxon as being composed of four irregular, indistinct bands that extend from one semicell to the other, without any separation in the isthmus region, fully coincident with the material examined here (Fig. 44).

Pleurotaenium gloriosum (Turner) West \& G.S.West, Bot. Tidsskr. 24: 167. 1901.

Docidium gloriosum Turner 1893, S. 30, taf. 3, fig. 5. 1893. Fig. 45-47

Cells ca. 22-23.5 times longer than wide (980-1060 $\mu \mathrm{m}$ long by $43-45 \mu \mathrm{m}$ wide), apex $43-45 \mu \mathrm{m}$ wide, isthmus 38 $40 \mu \mathrm{m}$ wide, median constriction shallow, lateral margins undulating above the median swelling; apex with a single group of granules; cell walls hyaline, punctuated; apical view circular, capitulate; lateral and frontal views identical; chloroplasts ribbon-like, multiple; pyrenoids multiple. Distribution in Brazil: São Paulo (Azevedo 1984).

Material selected: Brazil. Bahia: Mata de São João, APA Litoral Norte, 15/II/2009, Oliveira et al. s.n. (HUEFS 155625); Esplanada, APA Litoral Norte, 28/II/2009, Oliveira \& Farias s.n. (HUEFS 155641); Conde, APA Litoral Norte, 01/III/2009, Oliveira \& Farias s.n (HUEFS 155754, HUEFS 155760).

Pleurotaenium gloriosum is similar to $P$. cylindricum (W.B.Turner) Schmidle var. stuhlmannii (Hieron.) Willi Krieg. in terms of their apex ornamentations, although the latter has a slightly wider cell apex and slender cells with greater cell length/width ratios.

Pleurotaenium gloriosum can also be compared to P. simplicissimum Grönblad var. insigne (Y.V. Roll) Willi Krieg., although the latter differs by having straight apical margins without lateral projections, relatively smaller cell dimensions and slightly undulating lateral margins just above the isthmus.

Pleurotaenium nodosum (Bailey) Lundell var. borgei (Grönblad) Willi Krieg. In Rabenh., Kryptog.Fl. Deutschl. 13(1): 437, pl. 47, fig. 4. 1937.

Pleurotaenium nodosum (Bailey) Lundell f. borgei Grönblad, Acta Soc. Fauna et Flora fenn. 47(4): 27, pl. 4, fig. 28. 1920. Fig. 48-51

Cells ca. 10-12 times longer than wide (380-410 $\mu \mathrm{m}$ long by $67.5-70 \mu \mathrm{m}$ wide), apex $35-37.5 \mu \mathrm{m}$ wide, isthmus 32.5 $35 \mu \mathrm{m}$ wide, median constriction shallow, angles rounded; lateral margins with four undulations, apex expanded, bordered by a single crown of subglobose granules composed of 5-6 granules that can be seen in frontal view; cell walls hyaline, coarsely punctuated; chloroplasts parietal, ribbonlike, multiple pyrenoids.

Distribution in Brazil: Mato Grosso (Borge 1903); São Paulo (Azevedo 1984).

Material selected: Brazil. Bahia: Entre Rios, APA Litoral Norte, 26/VII/2009, Oliveira et al. s.n. (HUEFS 155741); Conde, APA Litoral Norte, 11/VII/2009, Oliveira et al. s.n. (HUEFS 155720), 02/VIII/2009, Oliveira \& Moura s.n. (HUEFS 155802, HUEFS 155819).

The variety borgei (Grönblad) Krieger was originally proposed by Grönblad (1945) based on material collected in the state of Pará. According to the author, this variety differs from the typical variety of the species by having cells that are more than 7 times longer than they are wide, an extended region between the nodule rings, subcylindrical semicells, and a straight or concave margin between the rings, with 6-10 nodules per ring.

Pleurotaenium ovatum (Nordst.) Nordst. var. ovatum, Öfv. K. Vet.-Akad. Förh. 3: 18. 1877

Docidium ovatum Nordst., Vidensk. Meddr dansk naturh. Foren. 1869 (14/15): 205, pl. 3, fig. 37 a, e. 1869.

Fig. 52

Cells ca. 2.8 times longer than wide $(390-410 \mu \mathrm{m}$ long by $140-142.5 \mu \mathrm{m}$ wide), apex $40-42.5 \mu \mathrm{m}$ wide, isthmus $75-$ $77.5 \mu \mathrm{m}$ wide, median constriction shallow, lateral margins strongly concave; apex with a single set of granules composed of 5-6 granules that can be seen in frontal view; cell walls hyaline, punctuated; apical view circular, capitulate; chloroplasts ribbon-like, multiple; pyrenoids multiple.

Distribution in Brazil: Mato Grosso (Borge 1925); São Paulo (Bicudo \& Bicudo 1962; Azevedo 1984; Bicudo et al. 1998). Material selected: Brazil. Bahia: Esplanada, APA Litoral Norte, 14/II/2009, Oliveira \& Farias s.n. (HUEFS 155638).

This species was proposed, based on material collected in the state of Minas Gerais by Nordstedt (1869), as Docidium ovatum, and was transferred to the genus Pleurotaenium by the same author in 1877 .

Morphologically, Pleurotaenium ovatum var. ovatum can easily be confused with $P$. maskellii Sux \& Venk, although 
the latter differs basically by having chloroplasts in the shape of plaques, rather than ribbons.

Pleurotaenium sceptrum (H.Roy) West \& G.S. West var. sceptrum, Trans. Linn. Soc. Lond.: sér. 2, 5(5): 235, pl. 13, fig. 6. 1896.

Docidium sceptrum Roy, Scott. Nat.: sér. 2, 1: 39. 1883. Fig. 53-55

Cells ca. 24-27 times longer than wide (340-435 $\mu \mathrm{m}$ long by $14-16 \mu \mathrm{m}$ wide), apex 10-11.5 $\mu \mathrm{m}$ wide, isthmus $12.5-14$ $\mu \mathrm{m}$ wide, lateral margins parallel, slightly attenuated towards the apex; median constriction shallow, apex with a single set of 4-5 pointed spines; cell walls hyaline, punctuated; chloroplast axial.

Distribution in Brazil: São Paulo (Azevedo 1984).

Material selected: Brazil. Bahia: Mata de São João, APA Litoral Norte, 11/I/2009, Oliveira \& Moura s.n. (HUEFS 155603); Esplanada, 12/VII/2009, Oliveira et al. s.n. (HUEFS 155731), Oliveira \& Farias s.n. (HUEFS 155641), Entre Rios, APA Litoral Norte, 26/VII/2009, Oliveira et al. s.n. (HUEFS 155776).

Due to an error that occurred when the species description was first published, Pleurotaenium sceptrum var. sceptrum is frequently cited in the literature as $P$. tridentulum (Wolle) West. Following the International Code of Nomenclature for Algae, Fungi, and Plants, the older, validly published name has precedence, and $P$. tridentulum is therefore the taxonomic synonym of $P$. sceptrum var. sceptrum.

Azevedo (1984) described smaller cell dimensions $(160-320 \mu \mathrm{m} \times 9-18 \mu \mathrm{m})$ for material collected in the state of São Paulo. However, with the exception of those cell dimensions, the specimens we collected in the state of Bahia coincide with the descriptions and illustrations provided by that author.

Pleurotaenium simplicissimum Grönblad var. insigne (Y.V.Roll) H.Krieg., In Rabenhorst, Kryptogamen-Fl. Deutschl. 13(1): 419, pl. 44, fig. 10. 1937.

Pleurotaenium insigne Y.V.Roll, Bot. Mat. Spor. Rast. Glavn. Bot. Sada RSFSR 2: 41, fig. 12. 1923.

Fig. 56-58

Cells ca. 20-22 times longer than wide (800-940 $\mu \mathrm{m}$ long by $40-45 \mu \mathrm{m}$ wide), apex $35-40 \mu \mathrm{m}$ wide, isthmus 35 $40 \mu \mathrm{m}$ wide, median constriction shallow, lateral margins slightly undulating above the median swelling; apex with a single set of granules; cell walls hyaline, punctuated; apical view circular, capitulate; lateral and frontal views identical; chloroplasts ribbon-like, multiple; pyrenoids multiple. Distribution in Brazil: São Paulo (Azevedo 1984).

Material selected: Brazil. Bahia: Camaçari, APA Lagoas de Guarajuba, 09/III/2007, Oliveira et al. s.n. (HUEFS 125533), 20/VII/2007, Oliveira et al. s.n. (HUEFS 125591); APA Rio Capivara, 12/I/2007, Oliveira \& Oliveira s.n. (HUEFS 125518), 25/VIII/2007, Oliveira et al. s.n. (HUEFS 125604); Mata de São João, APA Litoral Norte, 15/II/2009, Oliveira
\& Farias s.n. (HUEFS 155634); Entre Rios, APA Litoral Norte, 26/VII/2009, Oliveira et al. s.n. (HUEFS 155741); Conde, APA Litoral Norte, 01/III/2009, Oliveira et al. s.n. (HUEFS 155760), 02/VIII/2009, Oliveira \& Moura s.n. (HUEFS 155819).

Morphologically, Pleurotaenium simplicissimum var. insigne is similar to P. gloriosum, although the latter differs by having cells that are approximately 28 times longer than they are wide.

The specimens studied here fit the original description of P. simplicissimum var. insigne by Krieger (1937), who described its cells as being approximately 22-24 times longer than they are wide.

Pleurotaenium trabecula (Ehrenb.) ex Nägeli var. trabecula f. trabecula, Gatt. einz. Algen. 104, pl. 6, fig. A. 1849.

Closterium trabecula Ehrenb., Physik, Klas. 1831: 68, pls I-IV. 1832.

Fig. 59-62

Cells ca. 11-14 times longer than wide (390-560 $\mu \mathrm{m}$ long by $34-40 \mu \mathrm{m}$ wide), apex $28-35 \mu \mathrm{m}$ wide, isthmus $30-38 \mu \mathrm{m}$ wide, median constriction shallow; lateral margins parallel, narrowing slightly towards the apex, a single basal intumescence, conspicuous, sometimes 1-2 slight undulations above the basal intumescence; apical margins truncated, retuse, smooth, angles subquadrangular; cell walls hyaline, punctuated; chloroplasts parietal, various, ribbon-like; multiple pyrenoids.

Distribution in Brazil: Bahia (Förster 1964); Goiás (Prescott 1957; Förster 1964); Minas Gerais (Bicudo 1969); Pará (Grönblad 1945; Thomasson 1971); Paraná (Cetto et al. 2004); Rio de Janeiro (Sophia 1999); São Paulo (Borge 1918). Material selected: Brazil. Bahia: Camaçari, APA Lagoas de Guarajuba, 09/III/2007, Oliveira et al. s.n. (HUEFS 125526, HUEFS 125530); APA Rio Capivara, 09/III/2007, Oliveira et al. s.n. (HUEFS 125549); 20/VII/2007, Oliveira et al. s.n. (HUEFS 125583); Mata de São João, APA Litoral Norte, 11/I/2009, Oliveira \& Moura s.n. (HUEFS 155603, HUEFS 155610); 15/II/2009, Oliveira \& Moura s.n. (HUEFS 155634); Conde, APA Litoral Norte, 11/VII/2009, Oliveira et al. s.n. (HUEFS 155720).

Morphologically, Pleurotaenium trabecula var. trabecula f. trabecula and P. ehrenbergii var. ehrenbergii are very similar, although the latter differs by having an apex ornamented with a ring of 16 subglobose or slightly elongated granules.

Förster (1964) analyzed specimens from the states of Bahia and Goiás and reported a wider range of cell dimensions (593-742 $\mu \mathrm{m}$ in length) than that found in the present study.

Pleurotaenium trabecula (Ehrenb.) ex Nägeli var. elongatum Cedergr. f. elongatum Ark. Bot. 13(4): 12. 1913. Closterium trabecula Ehrenb., Phys. Klas. 1831: 1-154, pls. I-IV. 1831.

Fig. 63-65

Cells ca. 19-21 times longer than wide (480-660 $\mu \mathrm{m}$ long by $24-33 \mu \mathrm{m}$ wide), apex 18-28 $\mu \mathrm{m}$ wide, isthmus $20-25 \mu \mathrm{m}$ 

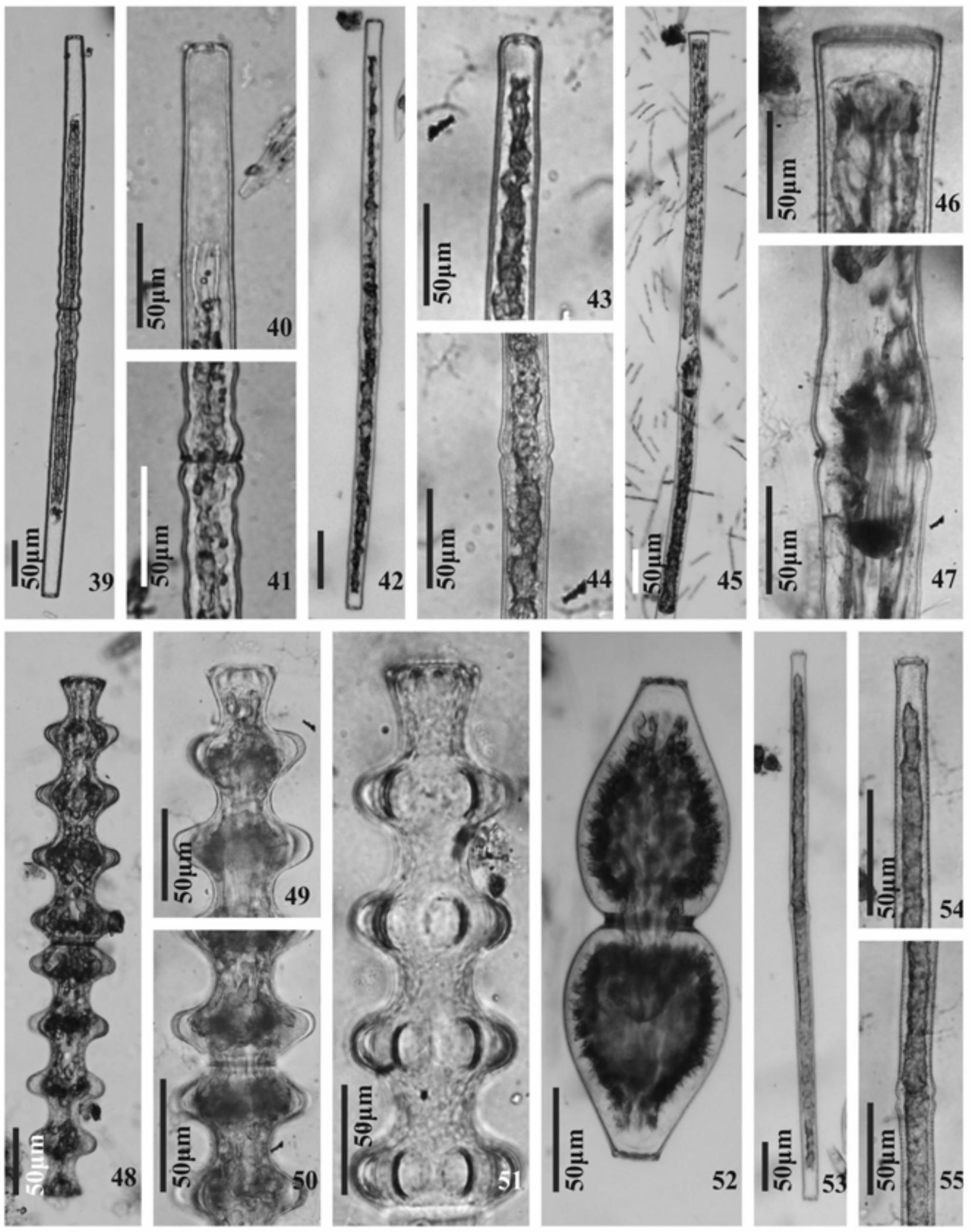

Figures 39-41. Fig. 39. Pleurotaenium ehrenberguii (Béb. Ex Ralfs) Delponte var. ehrenbergii; Fig. 40. Detail of the apex; Fig. 41. Detail of the isthmus; Fig. 42-44. Pleurotaenium ehrenbergii var. elongatum West: 43. Detail of the apex, 44. Detail of the isthmus; Fig. 45-47. Pleurotaenium gloriosum (W.B. Turner) West \& G.S. West: 46. Detail of the apex, 47. Detail of the isthmus; Fig. 48-51. Pleurotaenium nodosum (Bailey) P.Lundell var. borgei (Grönblad) Willi Krieg.: 49. Detail of the apex, 50. Detail of the isthmus, 51. Detail of cell walls punctuated; Fig. 52. Pleurotaenium ovatum (Nordst.) Norsdt. var. ovatum; Fig. 53-55. Pleurotaenium sceptrum (H.Roy) West \& G.S. West var. sceptrum: 53. Detail of the apex, 54. Detail of the isthmus. 
wide, median constriction shallow; lateral margins parallel, a single basal intumescence, 1-2 slight undulations above the intumescence, apical margins retuse, smooth, angles subquadrangular; cell walls hyaline, punctuated; chloroplasts parietal, ribbon-like, multiple; pyrenoids multiple.

Distribution in Brazil: Amazonas (Förster 1969); Bahia (Förster 1964), Pará (Grönblad 1945); São Paulo (Azevedo 1984).

Material selected: Brazil. Bahia: Camaçari, APA Lagoas de Guarajuba, 09/III/2007, Oliveira et al. s.n. (HUEFS 125528), 25/VIII/2007, Oliveira et al. s.n. (HUEFS 125618); APA Rio Capivara, 09/III/2007, Oliveira et al. s.n. (HUEFS 125555), 25/VIII/2007, Oliveira et al. s.n. (HUEFS 125601); Esplanada, APA Litoral Norte, 28/II/2009, Oliveira \& Farias s.n. (HUEFS 155612); Mata de São João, APA Litoral Norte, 15/II/2009, Oliveira \& Moura s.n (HUEFS 155625), Conde, APA Litoral Norte, 01/III/2009, Oliveira \& Farias. s.n. (HUEFS 155658, HUEFS 155660), Entre Rios, APA Litoral Norte, 26/VII/2009, Oliveira et al. s.n. (HUEFS 155752).

The variety elongatum differs from the typical variety of the species in terms of the length/width ratios of its cells, the cells of the former being 19-21 times longer than they are wide, compared with 12-17.7 times longer for the latter.

According to Prescott et al. (1975), individuals of Pleurotaenium trabecula var. elongatum can be up to 28 times longer than their maximum diameter.

Pleurotaenium tridentulum (Wolle) West var. tenuissimum Grönblad \& Croasdale Acta Bot. Fenn. 69: 30, figs. 33, 34. 1965.

Docidium tridentulum Wolle, Bull. Torr. Bot. Club 11(2): 14. 1884.

Fig. 66-68

Cells ca. 23-26 times longer than wide (260-275 $\mu \mathrm{m}$ long by $10-11.5 \mu \mathrm{m}$ wide), apex 5-6 $\mu \mathrm{m}$ wide, isthmus $9-10 \mu \mathrm{m}$ wide, median constriction shallow; lateral margins parallel, narrowing toward the apex, apical margins undulating, smooth, angles subquadrangular; cell walls hyaline, smooth; chloroplast axial; pyrenoids multiple.

Distribution in Brazil: Amazonas (Förster 1969; 1974); Pará (Scott et al. 1965).

Material selected: Brazil. Bahia: Mata de São João, APA Litoral Norte, 14/III/2009, Oliveira \& Moura s.n. (HUEFS 155703); Conde, APA Litoral Norte, 02/VIII/2009, Oliveira et al. s.n. (HUEFS 155819).

Pleurotaenium tridentulum var. tenuissimum differs from the typical variety of the species by having semicells with parallel lateral margins, undulating apical margins, and acute angles, whereas the typical variety shows semicells that narrow slightly towards the apex, which is ornamented with four short, occasionally curved, spines.

Pleurotaenium verrucosum (Bailey) P.Lundell var. verrucosum f. verrucosum, Nova Acta Reg. Soc. Scient. Upsal. 3, 8: 6. 1871 .
Closterium verrucosum Bailey, Amer. J. Sc. \& Arts 51 [sér. 2: 1] 127, fig. 4. 1846.

Fig. 69-70

Cells ca. 14-15.4 times longer than wide (385-420 $\mu \mathrm{m}$ long by $25-30 \mu \mathrm{m}$ wide), apex 20-24 $\mu \mathrm{m}$ wide, isthmus 18 $20 \mu \mathrm{m}$ wide, median constriction shallow; lateral margins parallel, apical margins straight, ornamented with a single row of conical granules, angles subquadrangular; cell walls hyaline, decorated with rounded or subquadrangular plaques arranged in transversal rows, a single row of distinctly smaller plaques near the isthmus, a single row of elongated plaques near the apex; chloroplasts parietal, ribbon-like, multiple pyrenoids.

Distribution in Brazil: Amazonas (Thomasson 1971); Mato Grosso (Borge 1925); Pará (Grönblad 1945).

Material selected: Brazil. Bahia: Camaçari, APA Lagoas de Guarajuba, 20/VII/2007, Oliveira et al. s.n. (HUEFS 125596), 25/VIII/2007, Oliveira et al. s.n. (HUEFS 125602, HUEFS 125604, HUEFS 125605); Entre Rios, APA Litoral Norte, 26/VII/2009, Oliveira et al. s.n. (HUEFS 155776); Conde, APA Litoral Norte, 02/VIII/2009, Oliveira \& Moura s.n. (HUEFS 155819).

The first record of Pleurotaenium verrucosum (Bailey) P.Lundell var. verrucosum f. verrucosum in Brazil was published by Grönblad (1945). The author presented a brief description of the species based on collections made in the state of Pará; the material studied here was fully coincident with that description.

Tetmemorus Ralfs ex Ralfs 1848

Tetmemorus brebissonii (Menegh.) Ralfs ex Ralfs var. brebissonii, Annls Mag. Nat. Hist. 14: 257, pl. 8, fig. 1. 1844. Closterium brebissonii Menegh. Linnea. 1840.

Fig. 71-72

Cells ca. 4.6-4.8 times longer than wide (118.5-121.5 $\mu \mathrm{m}$ long by $24.5-26 \mu \mathrm{m}$ wide), isthmus $21.5-22.5 \mu \mathrm{m}$ wide, median constriction shallow; semicell oblong, lateral margins smooth, parallel to each other, apical margins rounded, a single median incision, shallow, closed; cell walls hyaline, with parallel longitudinal grooves, interrupted by pores; chloroplast axial; pyrenoids sparse, multiple.

Distribution in Brazil: Bahia (Martins \& Bicudo 1987; Bicudo \& Martins 1989); Mato Grosso (Borge 1903); São Paulo (Bicudo 1969).

Material selected: Brazil. Bahia: Mata de São João, APA Litoral Norte, 11/I/2009, Oliveira \& Moura s.n. (HUEFS 155599, HUEFS 155603, HUEFS 155610); 14/III/2009, Oliveira \& Moura s.n. (HUEFS 155706); Entre Rios, APA Litoral Norte, 26/VII/2009, Oliveira et al. s.n. (HUEFS 155754, HUEFS 155760).

Martins \& Bicudo (1987) noted the overlapping of the minimum limits of the cell lengths of individuals of the typical variety with the maximum limits of representatives of Tetmemorus brebissonii var. minor De Bary, in addition to a pronounced concavity on the lateral margin of the semicell just above the basal intumescence. 
Prescott et al. (1975) reported a much wider range of cell dimensions (100-264 $\mu \mathrm{m}$ long and 9-48 $\mu \mathrm{m}$ wide) in the descriptions of the material they identified.

Tetmemorus brebissonii (Menegh.) Ralfs ex Ralfs var. minor De Bary, Untersuch. Fam. Conjugat., p. 73. Pl. 5, fig. 19. 1858.

Closterium brebissonii Menegh. Linnea. 1840.

Fig. 73

Cells ca. 4 times longer than wide $(60-75 \mu \mathrm{m}$ long by $15-19 \mu \mathrm{m}$ wide), isthmus $12-15 \mu \mathrm{m}$ wide, median constriction shallow, median sinus open; semicell quadrangular, lateral margins smooth, parallel to each other, with a slight depression in the middle, apical margins rounded, a single median incision, shallow, closed; cell walls hyaline, with parallel longitudinal grooves interrupted by pores.

Distribution in Brazil: Bahia (Förster 1964).

Material selected: Brazil. Bahia: Mata de São João, APA Litoral Norte, 11/I/2009, Oliveira \& Moura s.n. (HUEFS 155599, HUEFS 155610); Conde, APA Litoral Norte, 01/ III/2009, Oliveira \& Farias s.n. (HUEFS 155658); Entre Rios, APA Litoral Norte, 26/VII/2009, Oliveira et al. s.n. (HUEFS 155754).

Tetmemorus brebissonii var. minor differs from the typical variety of the species by having smaller cell dimensions and lateral margins with slight depressions in the middle, above the swelling of the isthmus, as well as ample, rounded apical margins.

Tetmemorus granulatus (Bréb.) Ralfs var. attenuatus West, Jour. Linn. Soc. Bot., London 29: 132, pl. 20, fig. 7. 1892. Closterium granulatus Bréb. In Menegh. Linnea. 1840.

Fig. 74

Cells ca. 4-4.6 times longer than wide (107.5-138.5 $\mu \mathrm{m}$ long by 24-33 $\mu \mathrm{m}$ wide), isthmus 21-27.5 $\mu \mathrm{m}$ wide; median constriction shallow, median sinus open; semicell oblong, lateral margins smooth, slightly concave, delicately attenuating towards the apex, apical margins rounded, a single median incision, shallow, closed; cell walls hyaline, punctuated.

Distribution in Brazil: Bahia (Förster 1964; Martins \& Bicudo 1987)

Material selected: Brazil. Bahia: Esplanada, APA Litoral Norte, 14/II/2009, Oliveira \& Moura s.n (HUEFS 155614), 28/II/2009, Oliveira \& Moura s.n (HUEFS 155641); Mata de São João, APA Litoral Norte, 14/III/2009 (HUEFS 155703); Entre Rios, APA Litoral Norte, 26/VII/2009, Oliveira et al. s.n.(HUEFS 155748).

Tetmemorus granulatus var. attenuatus differs from the typical variety by having semicells that narrow towards the apex.

Prescott et al. (1975) questioned the merit of this variety, because the attenuation that characterizes it can be seen in both this and the typical variety of the species. Despite their commentaries, those authors accepted the variety attenuatus.
Tetmemorus laevis (Kutz.) Ralfs var. laevis, Brit. Desm.: 146, pl. 24, fig. 3. 1848.

Closterium leave Kutz. 1845, 132.

Fig. 75

Cells ca. 3.8 times longer than wide (120-135 $\mu \mathrm{m}$ long by 31-34 $\mu \mathrm{m}$ wide), isthmus $24-28 \mu \mathrm{m}$ wide, median constriction shallow, median sinus open; semicell oblong, lateral margins smooth, parallel to each other, or narrowing slightly towards the apex, apical margins rounded to truncated, a single median incision, shallow, closed; cell walls hyaline, punctuated, region near the isthmus smooth.

Distribution in Brazil: Amazonas (Förster 1969); Mato Grosso (Borge 1903); Pará (Scott et al. 1965); Rio de Janeiro (Nordstedt 1877; Krieger 1950; Sophia 1991).

Material selected: Brazil. Bahia: Entre Rios, APA Litoral Norte, 26/VII/2009, Oliveira et al. s.n.(HUEFS 155776, HUEFS 155779); Conde, APA Litoral Norte, 02/VIII/2009, Oliveira et al. s.n. (HUEFS 155802).

Prescott et al. (1975, pl. 56, figs. 1-3) illustrated three different shapes for Tetmemorus laevis var. laevis, one of their figures (fig. 2) resembling T. brebissonii var. minor De Bary in having an approximately oblong outline and parallel lateral margins.

Tetmemorus laevis (Kutz.) Ralfs var. borgei Kurt Först., Brit. Desm.: 146, pl. 24, fig. 3. 1848.

Closterium leave Kutz. 132, 1845.

Fig. 76-77

Cells ca. 3 times longer than wide (46-54 $\mu \mathrm{m}$ long by 15-17.5 $\mu \mathrm{m}$ wide) isthmus $12.5-15 \mu \mathrm{m}$ wide, median constriction shallow, median sinus closed; semicell subrectangular, lateral margins smooth, parallel to each other, apical margins rounded, a single median incision, shallow, closed; cell walls hyaline, punctuated.

Distribution in Brazil: Bahia (Martins \& Bicudo 1987); Rio de Janeiro (Sophia 1991).

Material selected: Brazil. Bahia: Mata de São João, APA Litoral Norte, 11/I/2009, Oliveira \& Moura s.n. (HUEFS 155599); Entre Rios, APA Litoral Norte, 26/VII/2009, Oliveira et al. s.n. (HUEFS 155776, HUEFS 155779); Conde, APA Litoral Norte, 02/VIII/2009, Oliveira \& Moura s.n. (HUEFS 155802).

Tetmemorus laevis var. borgei is very similar to the variety minutus of the same species, differing, however, by having oblong cells, parallel lateral margins, and a poorly defined isthmus.

Tetmemorus laevis (Kutz.) Ralfs var. minutus (De Bary) Willi Krieg. Brit. Desm.: 146, fig. 3; pl. XXIV. 1848. Closterium leave Kutz. Phyc. Germ., 132. 1845.

Fig. 78-79

Cells 3.2-3.4 times longer than wide (50-60 $\mu \mathrm{m}$ long by $15-20 \mu \mathrm{m}$ wide), isthmus $12.5-18.5 \mu \mathrm{m}$ wide, median constriction shallow, median sinus open; semicell oblong, lateral margins smooth, parallel to each other, apical mar- 

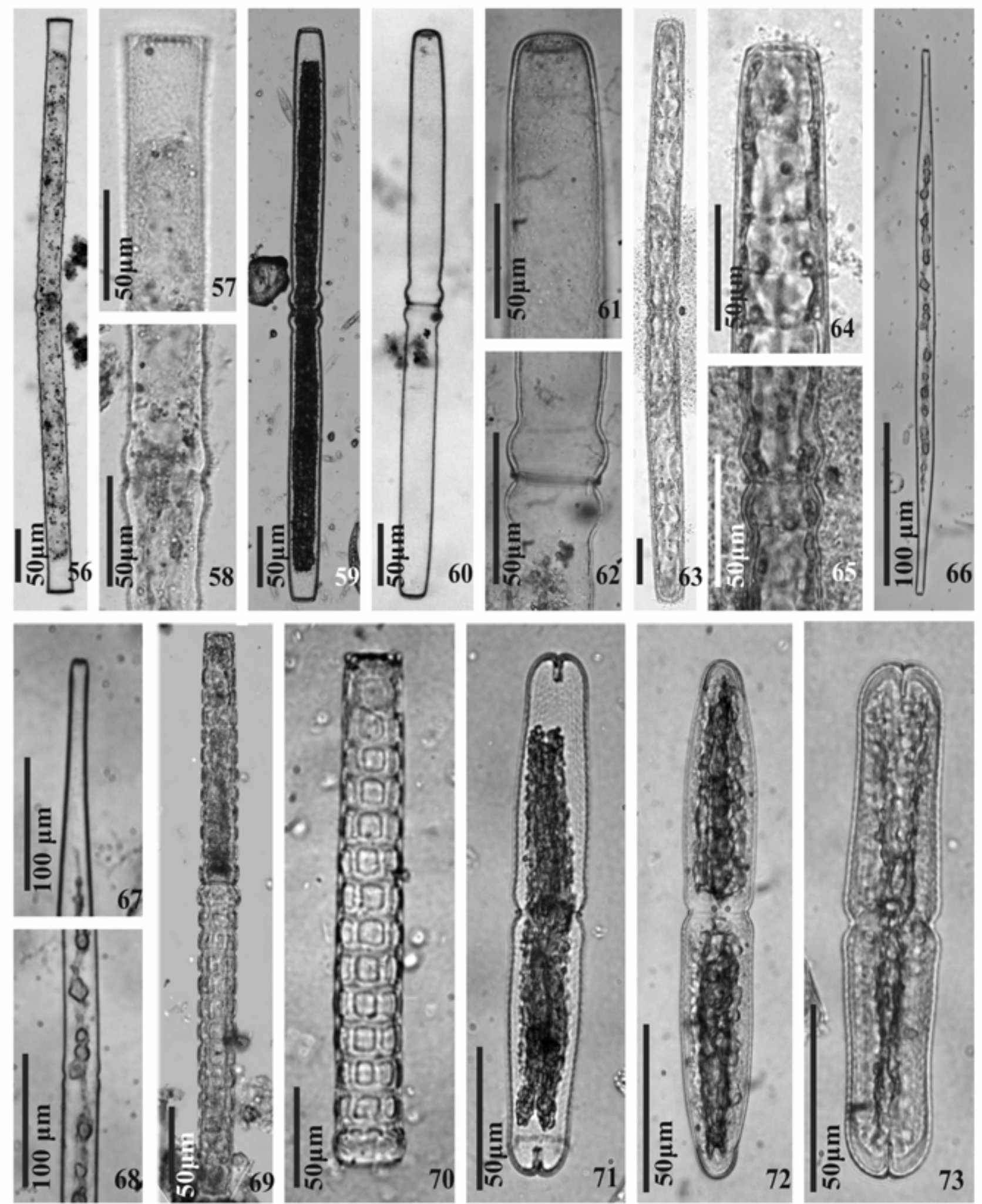

Figures 56-58. Fig. 56. Pleurotaenium simplicissimum Grönblad var. insigne (Y.V. Roll) Willi Krieg; Fig. 57. Detail of the apex; Fig. 58. Detail of the isthmus; Figures 59-62. Pleurotaenium trabecula (Ehrenb.) ex Nägeli var. trabecular f. trabecula: 61. Detail of the apex, 62. Detail of the isthmus; Fig. 63-65. Pleurotaenium trabecula var. elongatum Cedergr. f. elongatum: 64. Detail of the apex, 65. Detail of the isthmus; Fig. 66-68. Pleurotaenium tridentulum (Wolle) West var. tenuissimum Grönblad \& Croasdale: 67. Detail of the apex, 68. Detail of the isthmus; Fig. 69 and 70. Pleurotaenium verrucosum (Bailey) P. Lundell var. verrucosum f. verrucosum: 70. Detail of cell wall ornamentation; Fig. 71 and 72. Tetmemorus brebissonii (Menegh.) Ralfs ex Ralfs var. brebissonii: 71. Lateral taxonomic view; Fig. 73. Tetmemorus brebissonii (Menegh.) Ralfs ex Ralfs var. minor De Bary. 
gins rounded, a single median incision, shallow, closed; cell walls hyaline, punctuated.

Distribution in Brazil: Acre (Förster 1969); Pará (Scott et al. 1965); Rio Grande do Sul (Borge 1903; Sophia et al. 2005); Roraima (Förster 1963).

Material selected: Brazil. Bahia: Mata de São João, APA Litoral Norte, 14/III/2009, Oliveira \& Moura s.n. (HUEFS 155703); Entre Rios, APA Litoral Norte, 26/VII/2009, Oliveira et al. s.n (HUEFS 155776, HUEFS 155779); Conde, APA Litoral Norte, 02/VIII/2009, Oliveira \& Moura s.n. (HUEFS 155802).

Tetmemorus laevis var. minutus is very similar to the variety borgei of the same species, differing, however, by having cells that are attenuated towards the apex, with slight median swelling, and an open isthmus.

Förster (1963) described organisms with smaller cell dimensions (37-43 $\mu \mathrm{m} \times 12.5-13 \mu \mathrm{m})$ than those found for the material from Bahia.

\section{Triploceras Bailey, 1851}

Triploceras gracile Bailey var. bidentatum (Nordst.) Nordst. Bot. Notiser 1887: 163. 1887.

Pleurotaenium bidentatum Nordst. Öfvers. VetenskAkad. Förh. 34(3): 18, pl. 2, fig. 3. 1877.

Fig. 80-82

Cells ca. 14-16 times longer than wide (450-590 $\mu \mathrm{m}$ long by $30-38 \mu \mathrm{m}$ wide), apex $27.5-42 \mu \mathrm{m}$ wide, isthmus 25.5-38 $\mu \mathrm{m}$ wide, slight median constriction, conspicuous; semicells gradually narrowing towards the apex, 10-14 inferior verticils, 8-10 spines, 2 -furcated vertically in each verticil, upper portion larger, curved upwards, inferior portion reduced, horizontal or curved outward, 4-6 superior verticils of simple spines, curved upwards, apex of the semicell divided into two short processes, each with 1-2 simple spines, long, and one short spine between the long ones; cell walls hyaline, smooth, sometimes finely punctuated; axial stellate chloroplast; no pyrenoids observed.

Distribution in Brazil: Amazonas (Thomasson 1971; Förster 1969, 1974; Martins 1980); Mato Grosso (Borge 1925); Minas Gerais (Nordstedt 1869); Pará (Scott et al. 1965); São Paulo (Börgensen 1890; Borge 1918; Bicudo et al. 1998).

Material selected: Brazil. Bahia: Mata de São João, APA Litoral Norte, 11/I/2009, Oliveira \& Moura s.n. (HUEFS 155598, HUEFS 155599, HUEFS 155610); 15/II/2009, Oliveira \& Farias s.n. (HUEFS 155625).

This taxon differs from the typical variety of the species by having vertically bifurcated spines, the upper portion of the semicell having larger, bifurcated spines that are curved upwards, whereas the lower portion has smaller, horizontal or vertical spines, the apex of the semicell having two apical processes.

Of the 32 taxa identified, three are new additions to the algal flora of Brazil (Haplotaenium minutum var. minutum f. maius; Ichthyocercus angolensis; and Pleurotaenium coronatum var. nodulosum). Geographical distributions were
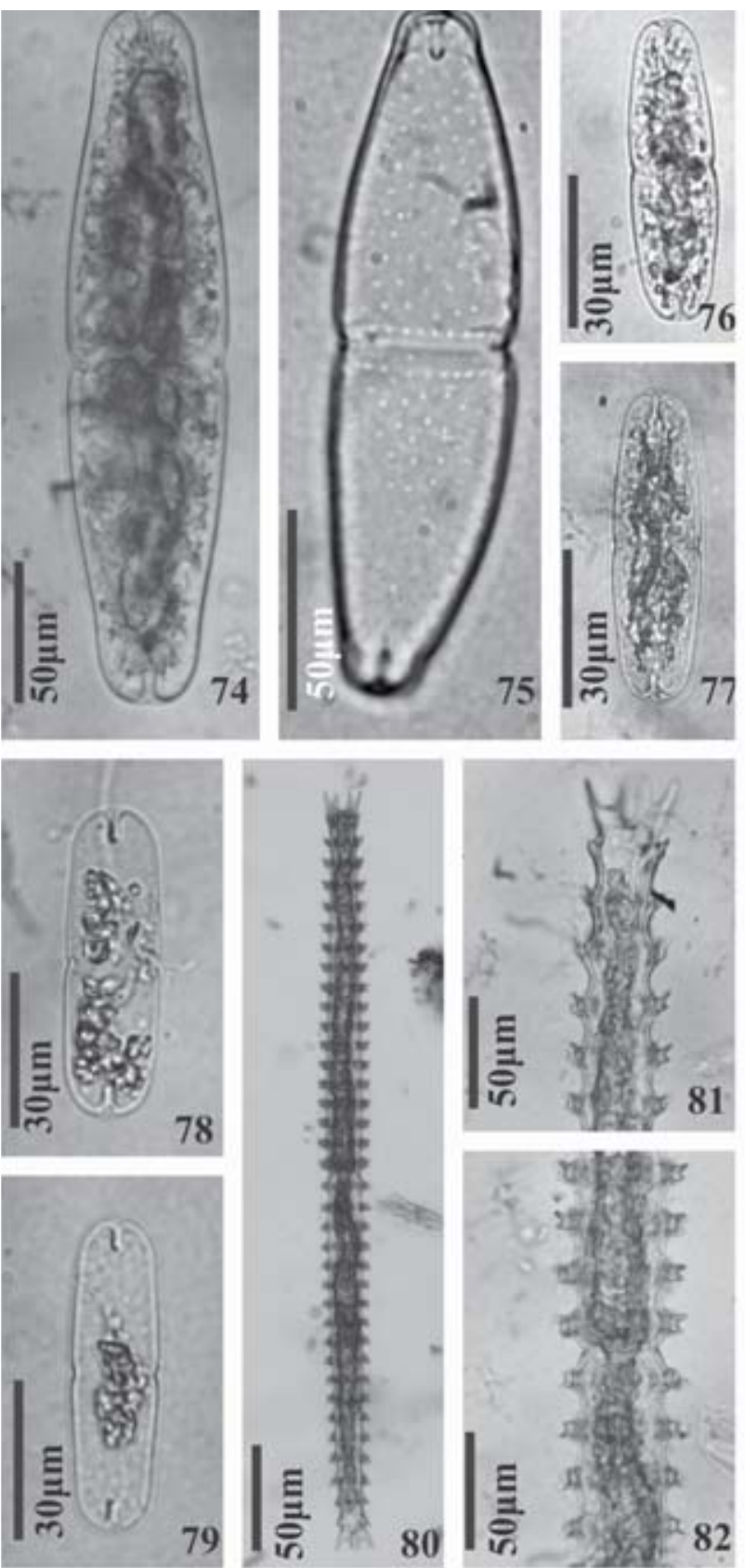

Figures 74-82. Fig. 74. Tetmemorus granulatus (Bréb.) Ralfs var. attenuatus West; Fig. 75. Tetmemorus laevis (Kütz.) Ralfs var. laevis; Fig. 76 and 77. Tetmemorus laevis var. borgei Kurt Först.; Fig. 78, 79. Tetmemorus laevis var. minutus (De Bary) Willi Krieg.; Fig. 80-82. Triploceras gracile Bailey var. bidentatum (Nordst.) Nordst.: 81. Detail of the apex, 82. Detail of the isthmus.

expanded to include the northeastern region of the country for 20 taxa: Docidium baculum var. baculum; Haplotaenium minutum var. cylindricum; $H$. minutum var. excavatum; $H$. minutum var. gracile; H. minutum var. latum; Pleurotaenium caldense var. cristatum; P. coroniferum; $P$. ehrenbergii var. ehrenbergii; $P$. ehrenbergii var. elongatum; $P$. gloriosum; $P$. nodosum var. borgei; $P$. ovatum var. ovatum; $P$. sceptrum var. sceptrum; $P$. simplicissimum var. insigne; $P$. trabecula var. elongatum f. elongatum; P. trabecula var. rectum; $P$. verrucosum 
var. verrucosum f. verrucosum; Tetmemorus laevis var. laevis; T. laevis var. minutus; and T. gracile var. bidentatum.

The genus Docidium has now been documented for the state of Bahia, and nine of the 13 taxa previously reported for the state were confirmed: Haplotaenium minutum var. minutum f. minutum; H. minutum var. crassum f. crassum; Pleurotaenium ehrenbergii var. elongatum; $P$. trabecula var. trabecula f. trabecula; P. trabecula var. elongatum f. elongatum; Tetmemorus brebissonii var. brebissonii; T. brebissonii var. minor; T. granulatus var. attenuatus; and T. laevis var. borgei.

\section{Acknowledgments}

The authors would like to thank the Universidade Estadual de Feira de Santana (UEFS, [Bahia] State University of Feira de Santana) and the Botanical Institute of the São Paulo State Department of the Environment for their logistical support. This study received financial support from the UEFS Graduate Program in Botany, for the fieldwork, as well as from the Brazilian Coordenação de Aperfeiçoamento de Pessoal de Nivel Superior (CAPES, Office for the Advancement of Higher Education; doctoral scholarship to IBO).

\section{References}

Acleto, C. \&Zúñiga, R. 1998. Introducción a las algas. Lima, Escuela Nueva S.A.

Azevedo, M.T.P. 1984. O gênero Pleurotaenium (Zygnemaphyceae) no estado de São Paulo: levantamento sistemático. Tese de doutorado em Ciências Biológicas - Botânica, Universidade Estadual Paulista, Campus de Rio Claro, São Paulo.

Bicudo, C.E.M. 1969. Contribution to the knowledge of the state of São Paulo, Brazil (including from the state of Minas Gerais). Nova Hedwigia 17(1-4): 443-549.

Bicudo, C.E.M. \& Bicudo, R.M.T. 1962. Contribuição ao conhecimento das Desmidiaceae do Parque Estadual das Fontes do Ipiranga, São Paulo, SP. Rickia 1: 207-225, pl. 1-5.

Bicudo, C.E.M. \& Martins, D.V. 1989. Desmídias (Zygnemaphyceae) de Itanagra, estado da Bahia, Brasil. Revista Brasileira de Biologia 49(1): 309-324.

Bicudo, C.E.M.; Sormus, L. \& Schetty, S.P. 1998. Criptógamos do Parque Estadual das Fontes do Ipiranga, São Paulo, SP. Algas, 11: Zygnemaphyceae (Desmidiaceae, 1: Haplotaenium, Pleurotaenium, Tememorus e Triploceras). Hoehnea 25(1): 33- 43.

Bicudo, C.E.M.; Sormus, L. \& Schetty, S.P. 1999. Criptógamos do Parque Estadual das Fontes do Ipiranga, São Paulo, SP. Algas, 12: Zygnemaphyceae (Desmidiaceae, 2: Desmidium, Groenbladia, Hyalotheca, Spondilosium e Teilingia). Hoehnea 26(1): 75-85.

Bicudo, C.E.M. \& Menezes, M. 2006. Gêneros de algas de águas continentais do Brasil: chave para identificação e descrição. 2 ed. São Carlos, RiMa.

Biolo, S.; Siqueira, N.S.; Bortolini, J.C. \& Bueno, C.B. 2008. Desmidiaceae (exceto Cosmarium) na comunidade perifítica em um tributário do Reservatório de Itaipu, Paraná, Brasil. Revista Brasileira de Biociências 6: 8-10.

Borge, O. 1903. Die Algen der ersten Regnellschen Expedition, 2: Desmidiaceae. Arkiv för Bottanik 1: 71-138.

Borge, O. 1918. Die von Dr.A. Löfgren in São Paulo gessammelten Süsswasseralgen. Arkiv för Botanik 15(13): 1-108.

Borge, O. 1925. Die von F.C. Hoehne Wahrend der espedition RooseveltRondon gessammelten Süsswasseralgen. Arkiv för Botanik 19(17): $1-56$.
Börgesen, O. 1890. Desmidiaceae. In: Warming, E. (Ed.). Symbolae ad floram Braziliae centralis cognoscendam. Videnskabelige Meddelelser fra den naturhistoriske Forening i Kjöbenhavn 46: 930-958, pl. 2-5.

Camargo, J.C.; Loverde-Oliveira, S.M.; Sophia, M.G. \& Nogueira, F.M.B 2009. Desmídias perifíticas da baía do Coqueiro, Pantanal Matogrossense - Brasil. Iheringia, Série Botânica 64(2): 25-41.

Cetto, J.M.; Leandrini, J.A.; Felisberto, S.A. \& Rodrigues, L. 2004. Comunidade de algas perifíticas no reservatório de Iraí Estado do Paraná, Brasil. Acta Scientiarum. Biological Sciences 26(1): 1-7.

Felisberto, S.A. \& Rodrigues, L. 2008. Desmidiaceae, Gonatozygaceae e Mesotaeniaceae na comunidade perifítica do reservatório de Salto do Vau (Bacia do Rio Iguaçu, PR). Hoehnea 35: 235-254.

Ferragut, C.; Lopes, M.R.M.; Bicudo, D.C.; Bicudo, C.E.M. \& Vercellino, I.S. 2005. Ficoflórula perifítica e planctônica (exceto Bacillariophyceae) de um reservatório oligotrófico raso (Lago do IAG, São Paulo). Hoehnea 32(2): 137-184.

Förster, K. 1963. Desmidiaceen aus Brazilien, 1: Nord Brazilien. Revue Algologique 7(1): 38-92.

Förster, K. 1964. Desmidiaceen aus Brazilien 2, Teil: Bahia, Goyaz. Piauhy und Nord-Brazilien. Hydrobiologia, Acta Hydrobiologica Hydrographica et Protistologica (3-4): 321-505.

Förster, K. 1969. Amazonische desmidien, 1. Amazoniana 2(1-2): 5-116. Förster, K. 1974. Amazonische desmidien, 2. Amazoniana 2(2): 135-242.

Gontcharov, A.A. \& Melkonian, M. 2005. Molecular phylogeny of Staurastrum Mayen ex Ralfs and related genera (Zygnematophyceae, Streptophyta) based on coding and noncoding rDNA sequence comparisons. Journal of Phycology 41: 887-889.

Graham, L.; Graham, J. \& Wilcox, L. 2009. Algae. 2 ed. San Francisco, Benjamin Cummings (Pearson).

Grönblad, R. 1945. De algus Braziliensibus: praecipue Desmidiacius, in regione inferiore fluminis Amazonas, Acta Societatis Scientiarum Fennicae, nov., ser. B. Helsinforsiave 2(6): 1- 43.

Irènèe-Marie, F. 1954. Les petits genres dans la famille des Desmidiaceae. (suite de l'étude sur les Desmidiées de la région des Trois-Rivières). Revue Algologique I: 2. Le Mans.

Kouwets, F.A.C. \& Coesel, P.F.M. 1984. Taxonomic revision of the conjugatophycean family Peniaceae on the basis of cell wall ultrastructure. Journal Phycology 20: 555-562.

Krieger, W. 1937. Die Desmidiaceen Europas. In: Rabenhorst's Kryptogamen-Flora von Deutschland, osterreich um der Schweiz. Leipzig: Akademische Verlasgsgesellschaft m.b.H. 13(1): I-VI + 377-712.

Krieger, W. 1950. Die Desmidiaceen Europas mit Berücksichtigung der auâereuropäischen Arten. In: Rabenhorst's Kryptogamen-Flora von Deutschland, Österreich und der Schweiz. Leipzig: Akademische Verlagsgesellschat m.b.H. 13(2): 117 .

Lopes, M.R.M. \& Bicudo, C.E.M. 2002. Desmidioflórula de um lago da planície de inundação do Rio Acre, Estado do Amazonas, Brasil. Acta Amazônica 33(2): 167-212.

Martins, D.V. 1982. Contribuição a ficologia da Amazônia, 3- Desmidioflórula dos lagos Cristalinos e São Sebastião, Estado do Amazônas: Gêneros Netrium, Closterium e Pleurotaenium. Acta Amazonica 12(2): 279-290.

Martins, D.V. \& Bicudo, C.E.M. 1987. Desmídias da Ilha de Itanharé, estado da Bahia, Brasil. Revista Brasileira de Biologia 47(1-2): 1-16.

Scott, A.M.; Grönblad, R. \& Croasdale, H. 1965. Desmids from the Amazon Basin, Brazil. Acta Botânica Fennica 69: 1-93.

Nordstedt, O. 1869. Desmidiaceae. Symbolae ad floram Braziliae centralis cognoscendam, 5. Videnskaps Meddel. Dansk Naturhist. Foren. Kjebenhavn 14-15: 233-234.

Nordstedt, C.F.O. 1877. Nonnulae algae aquae dulcis Brazilienses. Öfversigt af kongliga Vetenskaps - akademiens Förhandlingar 1877: 15-30.

Prescott, G.W. 1957. The Machris Brazilian expedition, Botany: Chlorophyta, Euglenophyta. Contributions in Science, Los Angeles, 11: 1-28.

Prescott, G.W.; Croasdale H.T. \& Vinyard W.C. 1975. A synopsis of North American desmids. Part II: Desmidiaceae: Placodermae. Section 1. London, University of Nebraska Press.

Rodrigues, L. \& Bicudo, D.C. 2001. Similarity among periphyton algal communities in a lentic-lotic gradient of the upper Paraná River floodplain, Brazil. Revista Brasileira de Botânica 24: 235-248. 
Růžička, J. 1977. Die Desmidiaceen Mitteleuropas. Vol. 1(1). Stuttgart. E. Schweizerbat'sche Verlagsbuchhandlung. VI+292p.

Sophia, M.G. 1991. Desmídias de hábito solitário (exceto Micrasterias C. Agardh ex Ralfs) do município do Rio de Janeiro e arredores, Brasil. Revista Brasileira de Biologia 51(1): 85-107.

Sophia, M.G. 1999. Desmídias de Ambientes Fitotélmicos Bromelícolas. Brazil. Revista Brasileira de Biologia 59(1): 141-150.

Sophia, M.G.; Dias, I.C. \& Araújo, A.M. 2005. Chlorophyceae and Zygnematophyceae from the Turvo State Forest Park, state of Rio Grande do Sul, Brazil. Revista Brasileira de Biologia 51: 85-107.
Thomasson, K. 1971. Amazonian desmids. Mémoires Institute Royal des Sciences Naturelles de Belgique: ser. 2, 86: 1-57.

Ungaretti, I. 1981. Desmídias (Zygnemaphyceae) de um açúde do Morro Santana, Porto Alegre, Rio Grande do Sul, Brazil. Iheringia, Série Botânica 27: 3-26.

Yinxin, W. \& Minjuan, Y. 2005. New desmids material from Donghu Lake, Wuhan, China. - Chinese Journal of Oceanology and Limnology 23(2): 210-217.

West, W. \& West, G.S. 1904. A monograph of the British Desmidiaceae. v. 1, London, The Ray Society. 